\title{
Earnings Management, Earnings Surprises, and Distressed Firms
}

\author{
John S. Howe ${ }^{1}, \mathrm{PhD}, \mathrm{CFA} \&$ Reza Houston ${ }^{2}, \mathrm{PhD}$ \\ ${ }^{1}$ Chair, Department of Finance, Missouri Bankers Chair and Professor of Finance, NACD Governance Fellow, \\ University of Missouri - Columbia, USA \\ ${ }^{2}$ Assistant Professor of Finance, Department of Accounting, Finance, Insurance, and Risk Management, Indiana \\ State University - Terre Haute, USA \\ Correspondence: John S. Howe, PhD, CFA, Chair, Department of Finance, Missouri Bankers Chair and Professor of \\ Finance, NACD Governance Fellow, University of Missouri - Columbia, USA. Tel: 1-573-882-5357
}

Received: November 21, 2015

Accepted: December 12, 2015 Online Published: December 16, 2015

doi:10.5430/afr.v5n1p64

URL: http://dx.doi.org/10.5430/afr.v5n1p64

\begin{abstract}
We examine the propensity of distressed firms to manage earnings and the impact of their earnings management on investor response to earnings. We find that distressed firms manage earnings upward and downward more than other firms. Distressed firms manage earnings upward significantly more than non-distressed firms after negative earnings surprises. Investor response to earnings surprises is smaller in magnitude for distressed firms. Investor response to positive earnings surprises of distressed firms is larger in magnitude than the response to negative earnings surprises. The change in bankruptcy probability after a negative earnings surprise is greater for distressed firms. Distressed firms have less post-announcement earnings drift. The results suggest that earnings management by distressed firms lowers earnings quality and weakens investor response. Our evidence has implications for investors, analysts, and compensation and audit committees.
\end{abstract}

Keywords: Earnings management, Earnings surprises, Standardized unexpected earnings, Financial distress

\section{Introduction}

Earnings management continues to be a concern despite the controls put into place by Sarbanes-Oxley legislation. (Note 1) Examples of earnings management techniques include the over/understatement of loan loss provisions, the deferment of fees, and "big bath" or "cookie jar reserve" techniques. Managers use these techniques to meet analyst earnings expectations (Bartov, Givoly, \& Hayn 2002; Doyle, Jennings, \& Soliman 2013), hide poor firm performance (Rangan 1998; Teoh, Welch, \& Wong 1998; Roychowdhury 2006), draw down assets, and avoid debt covenant violations (Watts \& Zimmerman 1986; Healy \& Papelu 1990; Defond \& Jiambalvo 1994; Franz, HassabElnaby, and Lobo 2014).

Managers also manipulate earnings when doing so is personally beneficial. A manager who inflates earnings benefits by being able to exercise stock options. However, in cases where the firm has historically underperformed, this route might not be possible due to a severely reduced share price. For the manager of this distressed firm, a more likely explanation for manipulating earnings upward is to avoid being fired (Huson, Malatesta, \& Parrino 2004; Kothari, Shu \& Wysocki 2009). This relationship between poor firm performance and managerial attrition is well documented, particularly in distressed firms (Dahya, McConnell, \& Travlos 2002; Huson et al. 2004).

Whether distressed firms as a whole engage in greater earnings management than non-distressed firms is still unclear. Most prior research on earnings management by distressed firms relates to the use of discretionary accruals in the period immediately prior to covenant violation or debt renegotiation (Saleh and Ahmed 2005; Beneish, Press, and Vargus 2012). Managers are often found to manipulate earnings upward in order to stave off covenant violation (Rosner 2003).

It is also not clear what impact the use of earnings management by distressed firms has on investor behavior. While the negative relationship between accruals and subsequent stock returns is well documented, there is very little evidence how investors immediately react to new information by distressed firms. If investors recognize the lower earnings quality of distressed firms, they should not only be less responsive to the earnings surprises of these firms, but the magnitude of the response to bad news could be far larger than the response to good news. 
In this paper, we examine whether distressed firms as a whole manage earnings to a greater extent than non-distressed firms and whether greater use of earnings management by distressed firms alters the response of investors to earnings surprises. We contribute to the literature on earnings management, earnings surprises, and distress in two ways. First, we demonstrate a positive link between earnings management and financial distress. Second, we show several fundamental differences in the investor response to earnings surprises of distressed firms and non-distressed firms.

If his or her firm were to consistently miss analyst earnings forecasts, the manager of a distressed firm would be more likely to be replaced than the manager of a non-distressed firm (Puffer \& Weintrop 1991; Bergstresser \& Philippon 2006). Because the managers of distressed firms are more likely to be fired for not meeting earnings expectations, these managers have greater incentive than managers of non-distressed firms to inflate earnings in order to meet or exceed analyst forecasts. We confirm that distressed firms engage in significantly more earnings management than non-distressed firms.

Distressed firms manage earnings both upward and downward more than non-distressed firms. There is a simple explanation for this. Distressed firms are expected to write off assets more frequently than other firms. They are therefore expected to have large negative accruals. Our results indicate that distressed firms have significantly larger negative discretionary accruals than non-distressed firms. However, distressed firms also have greater incentive to manage earnings upward and meet analyst expectations. This incentive is consistent with the expectation that managers of distressed firms inflate earnings to meet earnings expectations. We find distressed firms are significantly more likely than non-distressed firms to manage earnings upward.

In order to examine whether managers who are most likely to be fired inflate earnings more than other managers, we examine whether managers are more willing to manipulate discretionary accruals upward or downward after failing to meet earnings expectations in the previous quarter. After distressed firms miss analyst forecasts, managers of these firms might be more likely to engage in earnings management in order to avoid repeatedly missing analyst forecasts. Consistent with this conjecture, we find that distressed firms increase their signed abnormal accruals significantly more than non-distressed firms after missing an earnings announcement.

The decision to engage in earnings management impacts investor response to information provided by the firm. One of the most important pieces of information concerning a firm is the quarterly earnings report. If investors believe that the quarterly earnings are less credible, they will be less responsive to earnings surprises of firms that engage in greater levels of earnings management. We find this to be true. Investor response to earnings surprises of distressed firms is significantly smaller than the response to earnings surprises of non-distressed firms. The finding persists even after we control for size, book-to-market, analyst coverage, and information asymmetry.

Because distressed firms engage in greater earnings management than other firms, investors respond differently to the reactions of positive and negative earnings surprises. Previous research has highlighted two theories that explain the difference in the magnitude of the investor response for positive and negative earnings surprises. If investors believe that the firm is managing its earnings in order to meet analyst forecasts, their response to positive earnings surprises will be smaller in magnitude than for negative earnings surprises (Kothari, Shu, \& Wysocki, 2009). We refer to this as the earnings management effect.

We refer to the second effect impacting investor response to earnings surprises of distressed firms as the bankruptcy avoidance effect. If a firm exceeds analyst expectations, shareholders might infer that the likelihood the firm will enter bankruptcy has significantly decreased. Firms that default manage earnings downward in the year prior to default to improve their bargaining position with creditors (Saleh and Ahmed 2005). Positive earnings act as a signal that the firm will not default in the immediate future. The signaling cost is represented in the opportunity cost of a weaker bargaining position in the case of a default. According to this theory, the response to a positive earnings surprise of a distressed firm might be larger than the response to a negative earnings surprise.

Our findings reveal a difference in the relative magnitude of positive and negative investor responses for distressed and non-distressed firms. We first examine non-distressed firms and find that, consistent with Kothari et al. (2009), the magnitude of negative earnings surprises is larger than the magnitude of positive earnings surprises. Further, the bankruptcy effect appears to dominate the earnings management effect for distressed firms. Our results in this sample indicate that positive earnings surprises have significantly larger investor responses than negative earnings surprises.

To provide additional support for the bankruptcy avoidance hypothesis, we also examine the relationship between earnings surprises and the change in the probability of bankruptcy. We show a negative relationship between earnings surprise in the prior quarter and our primary measure of the probability of bankruptcy. We also find a significant positive relationship between the change in bankruptcy probability and the coefficient on the interaction between 
earnings surprises and distress. This finding is consistent with positive earnings surprises of distressed firms being associated with a larger decline in the probability of bankruptcy than equally positive earnings surprises of non-distressed firms.

In our final test, we examine the post-earnings announcement drift of distressed firms. Distressed firms are often smaller, less liquid, and less transparent than non-distressed firms. Because these characteristics are associated with slower investor responses and more momentum, we examine whether post-earnings announcement drift is larger for distressed firms than for non-distressed firms. Given our previous findings that earnings surprises of distressed firms have lower information content than the earnings of non-distressed firms, distressed firms should have less post-earnings announcement than non-distressed firms. We find that, after accounting for information asymmetry and investor attention, distressed firms do exhibit less post-earnings announcement drift than non-distressed firms. This finding supports our conjecture that earnings reports of distressed firms have lower quality than earnings reports of non-distressed firms.

In sum, our evidence provides strong support for the theory that managerial incentives impact the earnings quality of distressed firms and lead to changes in investor response to earnings surprises. Our results should be of interest to investors, analysts, and compensation and audit committees. Our findings also have implications for other managerial decisions that might lead to changes in investor behavior, e.g., initiation or discontinuation of earnings guidance. A simple extension of this paper could examine whether changes to earnings guidance influence investor response to earnings surprises.

In the next section, we provide a summary of the prior literature on the relationship between earnings management and distress. In section 3 we develop our hypotheses on earnings management and earnings surprises of distressed firms. We provide our data, models, and measures of distress in section 4 . We present our empirical results in section 5 and our conclusions in section 6.

\section{Literature Review}

Previous studies provide mixed evidence of the sign and magnitude of earnings management by distressed firms. When it is beneficial to the firm or the manager to increase discretionary accruals, a firm will do so. However, during periods when a firm requires a stronger negotiating position with a labor union or creditor, the firm will manipulate earnings downward.

In the period immediately preceding a covenant violation, firms manage accrual-based earnings upward. Rosner (2003) finds firms that enter bankruptcy exhibit a greater magnitude of income increasing discretionary accruals in the years prior to bankruptcy. DeFond and Jiambalvo (1994) find firms have positive discretionary accruals in the year prior to covenant violation. These results are supported by a large number of authors (Lara, Osma, and Neophytou 2009; Beneish, Press, and Vargus 2012; Etemadi, Dastgir, Momeni, and Dehkordi 2012). Campbell, Liu, and Martin (2011) find firms increase discretionary accruals prior to delisting.

Recent studies have found several cases where manipulate discretionary accruals downward. When a firm is likely to file Chapter 11 bankruptcy or default on a debt covenant, its negotiating position with its creditors can be strengthened by managing earnings downward prior to the default. Saleh and Ahmed (2005) find financially distressed Malaysian firms manipulate earnings downward in years when they renegotiate with lenders. DeAngelo, DeAngelo, and Skinner (1994) examine NYSE firms around dividend reductions and find these firms have large negative accruals, generally during contract renegotiations. Firms that expect to file for Chapter 11 in the next year also exhibit large negative accruals (Charitou, Lambertides, \& Trigeorgis, 2007).

The magnitude of discretionary accruals is dependent upon a number of factors, including governance (Peasnell, Pope, and Young 2005), analyst coverage (Yu 2008), firm size (Siregar and Utama 2008), and board activity (Ebrahim 2007). Peasnell et al. (2005) find a negative relationship between director independence and earnings management. Factors such as legal regime, firm culture, and manager background also explain the use of discretionary accruals (Han, Kang, Salter, and Yoo 2010).

\section{Hypothesis Development}

\subsection{Earnings Management and Firm Distress}

We expect a manager to be more willing to engage in a variety of management techniques in order to meet earnings expectations when his firm is performing poorly. Failure to meet earnings expectations is strongly associated with decreases in share price. Managers who consistently underperform market expectations are more likely to be replaced (Teoh, Welch, and Wong 1998) and managers of distressed firms are more likely to being fired for underperformance 
(Huson, Malatesta, \& Parrino 2004). Therefore they have greater incentive to manage earnings. Earnings management could be the difference between meeting earnings expectations and a negative earnings surprise. We therefore hypothesize:

\section{Hypothesis 1: Distressed firms manage engage in more earnings management than non-distressed firms.}

As several researchers have noted, managers inflate and deflate earnings based on the firm's ability to meet analyst expectations in the quarter. Bartov, Givoly, and Hayn (2002) find that firms manage earnings downward when actual earnings are above earnings forecasts. This "cookie jar" procedure allows the firms to manage earnings to a greater degree in the future. Degeorge, Patel, and Zeckhauser (1999) find that some firms manage earnings in order keep from reporting net losses. These authors find that the future performance of firms that inflate earnings upward is poorer than the future performance of firms that do not inflate earnings.

We examine whether distressed firms manage earnings more than non-distressed firms in the year after a negative earnings surprise. If the manager of a distressed firm consistently fails to meet analyst expectations, he is more likely to be replaced. Therefore, we hypothesize that his use of earnings management to meet forecasts will be more prevalent in the period immediately following a negative earnings surprise:

Hypothesis 2: Distressed firms that do not meet analysts' earnings forecasts in year t exhibit significantly greater earnings management in year $t+1$ than non-distressed firms that also do not meet analysts' earnings forecasts in year $t$.

\subsection{Investor Response to the Earnings Surprises of Distressed Firms}

Investor reaction to new information should be affected by the quality of the information. Firms with poor earnings quality are less able to credibly convey information to investors. Therefore, the investor response to the earnings surprises of these firms should be weaker than the investor response to earnings surprises of firms with better earnings quality.

Previous research on distressed firms and investor behavior around earnings announcements has been focused on the magnitude of the investor reaction. Campbell, Hilscher, and Szilagyi (2008) derive a bankruptcy prediction model using market data and show that the abnormal returns of distressed firms are significantly more positive than those of non-distressed firms around earnings announcements. A contribution of their paper is to provide an alternative model of distress to Ohlson's O-score (1980). We employ their measure of distress, hereafter referred to as the Campbell measure, in order to test the robustness of our results.

Bartov, Givoly, and Hayn (2002) find that distressed firms have significantly greater abnormal returns than non-distressed firms around earnings announcements. However, they do not control for information asymmetry or use a matched sample. It is possible that either differences in market capitalization or the level of information asymmetry between the firms could account for the larger returns for distressed firms. We use a matched sample and include a measure of information asymmetry as a control variable.

If investors are able to identify that managers of distressed firms are increasing discretionary accruals in order to meet earnings expectations, the investor response to positive earnings surprises by distressed firms will be tempered. Distressed firms manage earnings significantly more than non-distressed firms. Therefore, the market reaction to an earnings surprise will be smaller for distressed firms than non-distressed firms, given an equal earnings surprise:

Hypothesis 3a: Positive abnormal returns resulting from positive earnings surprises are smaller in magnitude for distressed firms than for non-distressed firms.

Hypothesis 3b: Negative abnormal returns resulting from negative earnings surprises are smaller in magnitude for distressed firms than for non-distressed firms.

Next we examine the difference in magnitude for positive and negative earnings surprises of distressed firms. Previous research has shown the price decrease associated with negative events to be larger in absolute terms than the price increase for positive information (Skinner \& Sloan, 2002; Dellavigna \& Pollet, 2009). One possible reason for this difference is the additional information associated with the firm's inability to meet analyst expectations. Managers will only underperform earnings expectations when they have no alternative. Given two equal-sized earnings surprises of different signs, the reward for exceeding expectations will be less than the penalty for not meeting expectations because firms can engage in earnings management. To some degree this effect should exist for both distressed and non-distressed firms.

Do investors respond more strongly to negative earnings surprises than positive earnings surprises? We propose two competing hypotheses. The earnings management effect refers to the loss of information associated with positive 
earnings surprises. If investors believe that a firm is managing its earnings, they will discount positive earnings surprises. If a firm reports a negative earnings surprise, investors will react much more strongly. They recognize that managers actively avoid negative earnings surprises. If a firm reports a negative earnings surprise, the surprise is significant negative information. The earnings management effect suggests:

Hypothesis 4a: The investor response to distressed firms not meeting analyst forecasts is larger than the response to meeting or beating analyst forecasts.

Hypothesis 4b: The investor response to non-distressed firms not meeting analyst forecasts is larger than the response to meeting or beating analyst forecasts.

Our second effect, which we call the bankruptcy avoidance effect, suggests that investors respond more strongly to positive earnings surprises of distressed firms. When a distressed firm reports a positive earnings surprise, investors might infer that the firm is less likely to enter bankruptcy. Previous researchers find bankruptcy costs, both direct and indirect, to be large (Kalay, Singhal, \& Tashjian, 2007; Chemmanur, Cheng, \& Zhang, 2013). Firms that are able to signal that they will not incur these costs should be rewarded by investors. As Charitou, et al. (2007) note, firms manage earnings downward in the year prior to default. Distressed firms that meet or beat earnings expectations will be rewarded by investors for the signal that they will not default in the near future. Therefore, investors will be more responsive to the positive earnings surprise of a distressed firm than to the negative earnings surprise of a distressed firm. The bankruptcy avoidance effect indicates:

Hypothesis 4c: The investor response to distressed firms not meeting analyst forecasts is smaller than the response to meeting or beating analyst forecasts.

Hypothesis 4d: The investor response to non-distressed firms not meeting analyst forecasts is larger than the response to meeting or beating analyst forecasts.

Implicit in the bankruptcy avoidance effect is the assumption that a positive earnings surprise significantly decreases the probability of entering bankruptcy. If failing to meet earnings expectations is not associated with an increase in the bankruptcy probability of the firm, we need another explanation for why distressed firms have larger abnormal returns for positive than negative earnings surprises. Rather than simply assume that distressed firms that meet earnings expectations in a given quarter have larger decreases in the probability of bankruptcy, we provide a test. We expect that distressed firms that beat earnings expectations in a quarter move significantly further away from bankruptcy. If true, it would support bankruptcy avoidance:

Hypothesis 5: Positive earnings surprises are followed by greater decreases in the probability of bankruptcy for distressed firms than those of non-distressed firms in the next quarter.

Distressed firms are smaller, riskier, less liquid, and garner less investor attention than non-distressed firms, qualities that have been associated with larger post-earnings announcement drift (Aberbanell \& Bernard 1992; Ke \& Ramalingegowda 2005; Sadka 2006; Zhang 2008; Price, Gatzlaff, \& Sirmans 2012). On average, distressed firms also trade less frequently.

Once we control for characteristics that previous authors have found to impact post-earnings announcement drift, the information content of the earnings announcement remains. If a manager uses discretionary accruals to meet earnings expectations, the earnings announcement does not accurately represent the performance of the firm. If the earnings surprise of a distressed firm provides less information to investors, we expect distressed firms to exhibit significantly less post-earnings announcement drift than non-distressed firms, after controlling for investor inattention, industry, time period, size of the earnings surprise, and the change in analyst forecasts.

Hypothesis 6: Distressed firms exhibit significantly less post-earnings announcement drift than non-distressed firms.

\section{Data, Models, and Measures of Distress}

\subsection{Data}

Accounting data come from Compustat and analyst earnings forecasts come from I/B/E/S. We use all available observations from U.S. firms publicly traded on the NYSE, AMEX, or NASDAQ that meet our requirements. We use both quarterly and annual data from 1989 to 2011. We eliminate financial firms (SIC codes 6000-6999) and utilities (SIC codes 4000-4999) from the sample. We eliminate firms with market capitalizations of less than $\$ 5$ million. We are left with 131,751 quarterly observations after setting these restrictions. We winsorize all continuous variables at the $1 \%$ and $99 \%$ levels. 
In tests of investor response, we create a matched sample to compare the investor response between distressed and non-distressed firms. Each distressed firm is matched with a unique non-distressed firm observation in the same quarter. The matched observations have the same 2-digit SIC code and the closest market capitalization. The market capitalization and standardized unexpected earnings must be between $50 \%$ and $200 \%$ of the market capitalization and standardized unexpected earnings of the distressed firm observation. Adjusting these limits does not change the significance of our results. Unexpected earnings of the distressed firm observations must have the same sign as the matched observation. We adjust the matched sample before each regression. If a distressed firm has no possible matches in the quarter, we do not include it in our matching regressions.

\subsection{Earnings Management Models}

Hypothesis 1 suggests that distressed firms engage in significantly greater levels of earnings management than do non-distressed firms. To measure earnings management, we calculate the level of discretionary accruals using the modified Jones model proposed by Dechow, Sloan, and Sweeney (1995). Discretionary accruals are a widely used proxy for earnings management. The Jones (1991) model regresses non-discretionary accruals on total assets, change in revenue, and property, plant, and equipment. The error term in this equation represents discretionary accruals. The Dechow, Sloan, and Sweeney (1995) model improves on the Jones model by accounting for revenue-based accruals.

To calculate discretionary accruals (DA), we first calculate total accruals. $\mathrm{TAC}_{\mathrm{i}, \mathrm{t}}$ indicates total accruals for firm $\mathrm{i}$ during year $\mathrm{t}$ calculated as:

$$
\mathrm{TAC}_{\mathrm{i}, \mathrm{t}}=\Delta \mathrm{ACT}_{\mathrm{i}, \mathrm{t}}-\Delta \mathrm{CHE}_{\mathrm{i}, \mathrm{t}}-\mathrm{LCT}_{\mathrm{i}, \mathrm{t}}+\Delta \mathrm{DLC}_{\mathrm{i}, \mathrm{t}}-\mathrm{DEP}_{\mathrm{i}, \mathrm{t}}+\varepsilon_{\mathrm{i}, \mathrm{t}}
$$

Where $\triangle \mathrm{ACT}_{\mathrm{i}, \mathrm{t}}$ is the change in current assets for firm i from quarter $\mathrm{t}-1$ to quarter $\mathrm{t} . \Delta \mathrm{CHE}_{\mathrm{i}, \mathrm{t}}$ is the change in cash. $\Delta \mathrm{LCT}_{\mathrm{i}, \mathrm{t}}$ is the change in current liabilities. $\Delta \mathrm{DLC}_{\mathrm{i}, \mathrm{t}}$ is the change in debt in current liabilities. $\mathrm{DEP}_{\mathrm{i}}$, is firm i's depreciation and amortization expense.

In line with previous studies of earnings management (Becker, DeFond, Jiambalvo, Subramanyam 1998; Klein 2002; Burgstahler \& Dichev 1997; Dechow, Sloan and Sweeney 1995), we use annual data to test Hypotheses 1 and 2. We calculate non-discretionary accruals as:

$$
\frac{\mathrm{TAC}_{\mathrm{i}, \mathrm{t}}}{\mathrm{TA}_{\mathrm{i}, \mathrm{t}-1}}=\mathrm{B}_{0} \frac{1}{\mathrm{TA}_{\mathrm{i}, \mathrm{t}-1}}+\mathrm{B}_{1} \frac{\Delta \mathrm{SALES}_{\mathrm{i}, \mathrm{t}}-\Delta \mathrm{REC}_{\mathrm{i}, \mathrm{t}}}{\mathrm{TA}_{\mathrm{i}, \mathrm{t}-1}}+\mathrm{B}_{2} \frac{\mathrm{PPE}_{\mathrm{i}, \mathrm{t}}}{\mathrm{TA}_{\mathrm{i}, \mathrm{t}-1}}+\varepsilon_{\mathrm{i}, \mathrm{t}}
$$

We use $\triangle$ SALES to indicate the change in sales for firm i from year t-1 to year $t$. PPE $E_{i, t}$ is the property, plant, and equipment for firm $\mathrm{i}$ during year t. $\triangle \mathrm{REC}_{\mathrm{i}, \mathrm{t}}$ is the change in receivables and $\mathrm{TA}_{\mathrm{i}, \mathrm{t}}$ is the total assets for firm $\mathrm{i}$ during year t. We deflate all variables by lagged total assets to eliminate size bias. We define discretionary accruals, $\mathrm{DA}_{\mathrm{i}, \mathrm{t}}$ as the actual deflated value of total accruals minus expected accruals based on the previous regression coefficients.

$$
\mathrm{DA}_{\mathrm{i}, \mathrm{t}}=\frac{\mathrm{TAC}_{\mathrm{i}, \mathrm{t}}}{\mathrm{TA}_{\mathrm{i}, \mathrm{t}-1}}-\left(\widehat{\mathrm{B}_{0}} \frac{1}{\mathrm{TA}_{\mathrm{i}, \mathrm{t}-1}}+\widehat{\mathrm{B}_{1}} \frac{\Delta \mathrm{SALES}_{\mathrm{i}, \mathrm{t}}-\Delta \mathrm{REC}_{\mathrm{i}, \mathrm{t}}}{\mathrm{TA}_{\mathrm{i}, \mathrm{t}-1}}+\widehat{\mathrm{B}_{2}} \frac{\mathrm{PPE}_{\mathrm{i}, \mathrm{t}}}{\mathrm{TA}_{\mathrm{i}, \mathrm{t}-1}}\right)
$$

The following model examines whether distressed firms engage in greater levels of earnings management than non-distressed firms (Hypothesis 1):

$$
\left|\mathrm{DA}_{\mathrm{i}, \mathrm{t}}\right|=\mathrm{B}_{0}+\mathrm{B}_{1} \text { Distress variable } \mathrm{i}_{\mathrm{i}, \mathrm{t}}+\mathrm{B}_{2} \mathrm{TA}_{\mathrm{i}, \mathrm{t}}+\mathrm{B}_{3} \mathrm{ROA}_{\mathrm{i}, \mathrm{t}}+\varepsilon_{\mathrm{i}, \mathrm{t}}
$$

We use various measures of firm distress including Ohlson's O-score and the measure of Campbell et al. (2009). $\mathrm{TA}_{\mathrm{i}, \mathrm{t}}$ is total assets. $\mathrm{ROA}_{i, t}$ is the return on assets for firm $\mathrm{i}$ in year $\mathrm{t}$.

We expect management of distressed firms to be more willing to engage in earnings management. Therefore, we expect DIST $\mathrm{i}_{\mathrm{i}, \mathrm{t}}$ to have a positive impact on the absolute value of discretionary accruals. Larger firms are subject to more scrutiny and managers of these firms may be less willing or able to engage in earnings management because it might be more easily detectable. Therefore, we expect total assets to have a negative relationship with earnings management. To measure income, we use each firm's net income divided by total assets $\left(\mathrm{ROA}_{\mathrm{i}, \mathrm{t}}\right)$. Firms that are less profitable will be more willing to manage earnings. Therefore, we expect a negative relation between our profitability ratio discretionary accruals.

Hypothesis 2 examines whether distressed firms that did not meet analysts' earnings forecasts in year t exhibit significantly greater earnings management in year $t+1$ than non-distressed firms. We use the Dechow et al. (1995) model to calculate discretionary accruals for both distressed and non-distressed firms. We use observations in which the firm had a negative annual earnings surprise during the previous year. We regress the absolute value of 
discretionary accruals on DIST, total assets, net income divided by total assets, book-to-market, and time and industry time fixed effects. Our model is given in equation 5:

$$
\left|\mathrm{DA}_{\mathrm{i}, \mathrm{t}}\right|=\mathrm{B}_{0}+\mathrm{B}_{1} \mathrm{DIST}_{\mathrm{i}, \mathrm{t}}+\mathrm{B}_{2} \mathrm{TA}_{\mathrm{i}, \mathrm{t}}+\mathrm{B}_{3} \mathrm{MISS}_{\mathrm{i}, \mathrm{t}}+\mathrm{B}_{4} \mathrm{DIST}^{*} \mathrm{MISS}_{\mathrm{i}, \mathrm{t}}+\mathrm{B}_{5} \mathrm{ROA}_{\mathrm{i}, \mathrm{t}}+\mathrm{B}_{6} \mathrm{BM}_{\mathrm{i}, \mathrm{t}}+\varepsilon_{\mathrm{i}, \mathrm{t}}
$$

DIST $_{i, t}$ is an indicator variable which equals one when the firm is distressed and zero otherwise. MISS $\mathrm{i}_{\mathrm{i}, \mathrm{t}}$ is an indicator variable which equals one if the firm failed to meet analyst. $\mathrm{BM}_{\mathrm{i}, \mathrm{t}}$ is the book to market ratio of the firm at the end of the previous fiscal year.

Distressed firms that do not meet analyst forecasts in year $\mathrm{t}-1$ will engage in greater earnings management than non-distressed firms that did not meet analyst forecasts in year t-1. DIST is our variable of interest in equation 5 . We therefore expect the coefficient on DIST to be positive. The interaction term between DIST and MISS indicates that a distressed firm failed to meet earnings in two consecutive years. We expect distressed firms that miss consecutive earnings expectations will be more likely to manage earnings downward in anticipation of a default.

\subsection{Measures of Distress}

Our primary measure of distress is Ohlson's O-score (1980). The O-score (OSCORE) uses a logistic model to identify distressed firms. Ohlson (1980) calculates the O-score as:

$$
\begin{gathered}
\text { OSCORE }=-1.32 * \ln (\text { Total Assets })+6.03 *\left(\frac{\text { Total Liabilities }}{\text { Total Assets }}\right)-1.43 *\left(\frac{\text { Working Capital }}{\text { Total Assets }}\right) \\
+0.076 *\left(\frac{\text { Current Liabilities }}{\text { Current Assets }}\right)-1.72 *(\text { Total Liabilities if TL }>\text { TA })-0.521\left[\frac{\text { Net Income }}{\mathrm{q}-\text { Net Income }_{\mathrm{q}-1}} \mid\right.
\end{gathered}
$$

Where the logistic function $P=\frac{e^{O S C O R E}}{I+e^{O S C O R E}}$ identifies firm observations as unlikely to default if they have O-scores close to zero. Ohlson pinpoints a critical value of 0.038 as the best number to balance Type I and Type II errors. We use this partition to create a binary variable where one indicates firm distress and zero indicates a non-distressed firm.

To test the robustness of our results, we use the method demonstrated by Campbell, Hilscher, and Szilagyi (2008). The Campbell et al. (2008) model is provided in equation 7. Default is defined in equation 8.

$$
\begin{aligned}
& \text { CSCORE=-9.16-20.26(NIMTAAVG)+1.42(TLMTA)-7.13(EXRETAVG)+1.41(SIGMA) } \\
& -0.045 \text { (RSIZE)-2.13(CASHMTA) }+0.075 \text { (MB)-0.058(PRICE) } \\
& P_{t-1}\left(Y_{i, t-1+j}=1 \mid Y_{i, t-2+j}=0\right)=\frac{1}{1+e^{\left(-\alpha_{j}-\beta_{j} x_{i, t-1}\right)}}
\end{aligned}
$$

In the model, $\mathrm{Y}_{\mathrm{i}, \mathrm{t}-2+\mathrm{j}}$ is a variable indicating whether firm $\mathrm{i}$ fails in month $\mathrm{t}-2+\mathrm{j}$. NIMTAAVG is a moving average of net income divided by the market value of the firm. TLMTA is a moving average of total liabilities divided by total market value of the firm. EXRETAVG represents the monthly log excess return on the firm's equity relative to the S\&P 500 index. SIGMA is the annualized standard deviation of the daily returns for the firm over the previous three months. We define RSIZE as the log ratio of a firm's market capitalization to the market capitalization of the S\&P 500. CASHMTA is the firm's percentage of short-term investments divided by market value of total assets. We denote each firm's market-to-book ratio using MB. Lastly, PRICE is the log price per share, which is truncated above $\$ 15$.

We use Model II from Campbell, Hilscher, and Szilagyi (2008). The subscript $\mathrm{j}$ is the number of months being forecast. $\mathrm{Y}=1$ indicates firm failure. The primary benefit of this model over the $\mathrm{O}$-score and $\mathrm{Z}$-score models is its reliance on market data rather than accounting data. (Note 2)

\subsection{Investor Response Models}

Hypotheses $3 \mathrm{a}$ and $3 \mathrm{~b}$ propose that distressed firms exhibit significantly smaller returns than non-distressed firms around earnings surprises. Previous research has found that distressed firms are less efficient (Becchetti and Sierra 2003), smaller and have less analyst coverage (Griffin and Lemmon 2002), have more restrictive covenants placed on debt issuances (Smith 1993), and have a higher cost of capital (Jensen 1991). The regression model is:

$$
\begin{aligned}
\text { RETURN }_{\mathrm{i}, \mathrm{q}}= & \mathrm{B}_{0}+\mathrm{B}_{1} \text { DIST }_{\mathrm{i}, \mathrm{q}}+\mathrm{B}_{2} \mathrm{SUE}_{\mathrm{i}, \mathrm{q}}+\mathrm{B}_{3} \text { DIST }_{\mathrm{i}, \mathrm{q}} * \mathrm{SUE}_{\mathrm{i}, \mathrm{q}}+\mathrm{B}_{4} \text { CHFOR }_{\mathrm{i}, \mathrm{q}} \\
& +\mathrm{B}_{5} \text { NUMEST }_{\mathrm{i}, \mathrm{q}}+\mathrm{B}_{6} \text { CHFOR }_{\mathrm{i}, \mathrm{q}} * \mathrm{DIST}_{\mathrm{i}, \mathrm{q}}+\varepsilon_{\mathrm{i}}
\end{aligned}
$$

Our dependent variable, RETURN $\mathrm{i}_{\mathrm{i}, \mathrm{q}}$, is the cumulative abnormal daily return during the event study. $\mathrm{SUE}_{\mathrm{i}, \mathrm{q}}$ is the value of the standardized unexpected earnings, for firm i in quarter q. (Note 3) $\mathrm{CHFOR}_{\mathrm{i}, \mathrm{q}}$ is the change between the first 
analyst forecast and last analyst forecast during the quarter. $\operatorname{NUMEST}_{i, q}$ is the amount of investor attention a firm receives.

We calculate abnormal returns using the Fama-French 3-factor model. Our primary coefficient of interest in this model is $B_{3}$. We calculate daily returns over the periods $(-1,1)$ and $(-3,3)$ where -1 represents one day before quarterly earnings per share are announced. If the earnings announcement occurs after the market closes at 4:30 Eastern time, we identify the announcement as occurring on the next trading day. We make this correction for nearly $40 \%$ of all announcements. We also test the robustness of our results using raw cumulative returns and find comparable results.

DIST $_{i, q}$ is an indicator variable for distress which equals one if the firm is distressed and zero otherwise. We expect this variable to have a significantly positive impact on RETURN $\mathrm{i}_{\mathrm{i}, \mathrm{q}}$. A significantly positive coefficient for DIST indicates that distressed firms are more likely to have positive changes in cumulative returns around earnings announcements.

$$
\mathrm{SUE}_{\mathrm{i}, \mathrm{q}}=\frac{\text { EARN }_{\mathrm{i}, \mathrm{q}}-\mathrm{TARG}_{\mathrm{i}, \mathrm{q}}}{\mathrm{P}_{\mathrm{i}, \mathrm{q}-1}}
$$

The variable SUE represents the standardized unexpected earnings and accounts for differences in the magnitude of the earnings surprise. We report the model in equation 10 . We calculate the earnings surprise using the Livnat and Mendenall model (2006). In recent years, Livnat and Mendenall's model has become the standard for earnings surprise calculation. EARN $\mathrm{i}_{\mathrm{i}, \mathrm{q}}$ is the actual earnings per share for firm $\mathrm{i}$ in quarter $\mathrm{q} . \mathrm{I} / \mathrm{B} / \mathrm{E} / \mathrm{S}$ provides earnings per share. TARG $_{\mathrm{i}, \mathrm{q}}$ is the target earnings and $\mathrm{P}_{\mathrm{i}, \mathrm{q}-1}$ is the closing share price on the last day of the previous quarter. We use three different target measures. Our primary measure of earnings surprise $\left(\mathrm{SUE}_{\mathrm{i}, \mathrm{q}}\right)$ uses the median of the last forecast made by each analyst in the period between 30 and three days before the earnings announcement as the target measure for the earnings surprise. Positive SUEs indicate that analysts under-estimated a firm's quarterly earnings. We expect positive earnings surprises to lead to positive cumulative returns and negative earnings surprises to lead to negative cumulative returns. This reasoning predicts $\mathrm{SUE}_{\mathrm{i}, \mathrm{q}}$ to have a positive coefficient.

We use two additional target measures as robustness checks. SUE_WALK ${ }_{i, q}$ is the earnings surprise based on a seasonal random walk model. We also perform tests with the earnings surprise from a seasonal random walk after the exclusion of special items. Although not reported, our results using this third measure of earnings surprise are not significantly different from those that use SUE_WALK $\mathrm{i}_{\mathrm{i}, \mathrm{q}}$.

We include the interaction between DIST $\mathrm{i}_{\mathrm{i}, \mathrm{q}}$ and $\mathrm{SUE}_{\mathrm{i}, \mathrm{q}}$ to compare the difference between distressed and non-distressed firm earnings surprises and returns. This interaction is our variable of interest in equation 9. A significant and positive $\mathrm{B}_{3}$ coefficient indicates that forecasting errors lead to larger-in-magnitude cumulative returns around the announcement date for distressed firms. A significant and negative $B_{3}$ coefficient would support our hypothesis that investors are less responsive to the earnings surprises of distressed firms.

We account for changes in analyst expectations with the variable $\mathrm{CHFOR}_{\mathrm{i}, \mathrm{q}}$. This variable represents the difference between the first and last analyst forecast in the 90 days prior to the announcement. If only one analyst forecasts quarterly earnings for a firm, this number is reported as zero. Changes in forecasts signal to investors that analysts have new information. Bartov, Givoly, and Hayn (2002) find that it is unlikely that analysts will account for the new information completely. The direction in which the change occurs will predict whether returns will be positive or negative. We thus expect CHFOR ${ }_{\mathrm{i}, \mathrm{q}}$ to be positively related to RETURN $\mathrm{i}_{\mathrm{i}, \mathrm{q}}$.

The interaction term $\mathrm{CHFOR}_{\mathrm{i}, \mathrm{q}} * \mathrm{DIST}_{\mathrm{i}, \mathrm{q}}$ shows differences that changes in analyst forecasts have for distressed and non-distressed firms. We expect changes in analyst forecasts to be more significant for non-distressed firms. If so, $\mathrm{B}_{6}$ will have a negative coefficient.

We include the number of analysts who forecast each firm's quarterly earnings, $\operatorname{NUMEST}_{\mathrm{i}, \mathrm{q}}$, to proxy for the amount of investor attention a firm receives. We expect that more investor attention will lead to less information asymmetry. Therefore, these firms will have smaller returns around earnings announcements. Therefore, we expect $\mathrm{NUMEST}_{\mathrm{i}, \mathrm{q}}$ to be negatively related to RETURN $\mathrm{i}_{\mathrm{i}, \mathrm{q}}$ (Note 4)

We provide an additional test of the magnitude of earnings surprises for distressed and non-distressed firms by separating our observations into positive and negative surprises. We then run the following regression:

$$
\text { RETURN }_{\mathrm{i}, \mathrm{q}}=\mathrm{B}_{0}+\mathrm{B}_{1} \text { DIST }_{\mathrm{i}, \mathrm{q}}+\mathrm{B}_{2} \mathrm{SUE}_{\mathrm{i}, \mathrm{q}}+\mathrm{B}_{3} \mathrm{CHFOR}_{\mathrm{i}, \mathrm{q}}+\mathrm{B}_{4} \mathrm{NUMEST}_{\mathrm{i}, \mathrm{q}}+\varepsilon_{\mathrm{i}}
$$

Our expectation is that the investor response to the earnings surprises of distressed firms is weaker than the investor response to non-distressed firms. Our variable of interest in this model is DIST. If the investor reaction is weaker for distressed firms, then we expect the coefficient on this variable to be negative in regressions that include only positive earnings surprises and positive in regressions that include only negative earnings surprises. 
Next we examine Hypothesis 4, whether investors in distressed firms are more responsive to positive or negative earnings surprises. Our model is provided in equation 12.

$$
\mid \text { Return }_{i, q}\left|=\mathrm{B}_{0}+\mathrm{B}_{1}\right| \mathrm{SUE}_{\mathrm{i}, \mathrm{q}} \mid+\mathrm{B}_{2} \mathrm{MEET}_{\mathrm{i}, \mathrm{q}}+\mathrm{B}_{3} \mathrm{NUMEST}_{\mathrm{i}, \mathrm{q}}+\mathrm{B}_{4} \mathrm{CHFOR}_{\mathrm{i}, \mathrm{q}}+\mathrm{B}_{5} \mathrm{ROA}_{\mathrm{i}, \mathrm{q}}+\varepsilon_{\mathrm{i}}
$$

The absolute value of the return over the event period is $\left|R E T U R N_{i, q}\right|$. To determine whether the magnitude of positive earnings surprises is greater than those of negative earnings surprises, we create the variable MEET. This indicator variable equals one if the firm met or exceeded earnings and equals zero otherwise.

If the earnings management effect dominates the bankruptcy avoidance effect, the coefficient of MEET will be significant and negative. If the bankruptcy avoidance effect dominates, then the coefficient of MEET will be significant and positive. We control for information asymmetry and profitability.

We test whether the change in distress is larger for distressed firms after an earnings surprise. To perform this test, we use the model 13.

$$
\begin{gathered}
\text { OSCORE }_{\mathrm{t}}-\text { OSCORE }_{\mathrm{t}-1}=\mathrm{B}_{0}+\mathrm{B}_{1} \mathrm{NEG}_{\mathrm{t}-1}+\mathrm{B}_{2} \text { DIST }_{\mathrm{t}-1}+\mathrm{B}_{3} \mathrm{NEG}_{\mathrm{t}-1} * \mathrm{DIST}_{\mathrm{t}-1} \\
+\mathrm{B}_{4} \ln (\mathrm{TA})+\mathrm{B}_{5} \mathrm{BM}+\mathrm{B}_{6} \mathrm{NUMEST}+\mathrm{B}_{7} \text { ROA }+\varepsilon_{\mathrm{i}}
\end{gathered}
$$

Our expectation is that the increase in probability of distress is larger for distressed firms that report negative earnings surprises in the previous quarter than for non-distressed firms that have negative earnings surprises in the previous quarter. Our bankruptcy avoidance hypothesis indicates that this change will be larger for distressed firms after negative earnings surprises. Therefore, we expect a positive coefficient on the interaction of $\mathrm{NEG}_{\mathrm{t}-1} * \mathrm{DIST}_{\mathrm{t}-1}$ to be positive.

Hypothesis 6 proposes that distressed firms exhibit significantly less post-earnings announcement drift than non-distressed firms. To test this hypothesis, we use the post-earnings announcement drift method of Livnat and Mendenhall (2006). We calculate cumulative abnormal returns as the return for firm i above the expected return for a similar-sized B/M portfolio provided on Ken French's website. We calculate long-term abnormal returns as the cumulative abnormal return starting two days after the earnings announcement and ending one day before the next quarter's earnings announcement. The regression model for this hypothesis is:

$$
\begin{gathered}
\mathrm{CAR}_{\mathrm{i},\left[\mathrm{q}_{1}+2, \mathrm{q}_{2}-1\right]}=\mathrm{B}_{0}+\mathrm{B}_{1} \text { DIST }_{\mathrm{i}, \mathrm{q}}+\mathrm{B}_{2} \mathrm{SUE}_{\mathrm{i}, \mathrm{q}}+\mathrm{B}_{3} \operatorname{DIST}_{\mathrm{i}, \mathrm{q}} * \operatorname{SUE}_{\mathrm{i}, \mathrm{q}} \\
+\mathrm{B}_{4} \mathrm{CHFOR}_{\mathrm{i}, \mathrm{q}}+\mathrm{B}_{5} \mathrm{CHFOR}_{\mathrm{i}, \mathrm{q}} * \operatorname{DIST}_{\mathrm{i}, \mathrm{q}}+\mathrm{B}_{6} \mathrm{NUMEST}_{\mathrm{i}, \mathrm{q}}+\varepsilon_{\mathrm{i}}
\end{gathered}
$$

We expect distressed firms will have less post-earnings announcement drift. Therefore, we expect the coefficient on the interaction term DIST ${ }_{\mathrm{i}, \mathrm{q}} * \mathrm{SUE}_{\mathrm{i}, \mathrm{q}}$ to be negative. If our results are consistent with Campbell, Hilscher, and Szilagyi (2008), the coefficient on DIST ${ }_{i, q}$ will be positive. In order to test Hypothesis 6, we use the matching procedure used to test Hypothesis 4.

Price drift is commonly attributed to investor underreaction to earnings surprises (Bernard and Thomas 1989; Aberbanell and Bernard 1992; Chudek, Truong, and Veerearaghavan 2011). Therefore, we expect standardized unexpected earnings to be positively related to abnormal returns. The change in analyst forecasts during the last three months of the forecast period is a proxy for the level of information asymmetry between management and investors. Bartov, Givoly, and Hayn (2002) find this measure to be significant and positively related to returns. We therefore expect CHFOR $_{\mathrm{i}, \mathrm{q}}$ to have a positive coefficient.

The number of analysts forecasting quarterly earnings is a measure of investor attention. We expect the number of analysts will be negatively associated with abnormal returns. We provide a robustness test for the relation between information asymmetry and post-earnings announcement drift by calculating the daily Q spread, which we define as the monthly average of the daily bid and ask price at the end of each trading day. We calculate this measure over the month prior to the earnings announcement for each firm. We expect that firms with greater information asymmetry, and therefore a larger spread, will have larger post-earnings announcement drift.

\subsection{Summary Statistics}

Panel A of Table 1 presents the summary statistics of the initial sample of distressed firms. We use Ohlson's O-score as our primary measure to calculate distress. There are 7,310 distressed firms included in our initial sample. Panel B provides the descriptive statistics for our non-distressed sample. Distressed firms are smaller and have less analyst coverage than non-distressed firms. Distressed firms are also less profitable and have lower turnover than non-distressed firms. 
Table 1. Summary Statistics of Sample Firms

Panel A: Distressed Firms

\begin{tabular}{lllll}
\hline Variable & $\mathrm{N}$ & Mean & Median & Std Dev \\
\hline Earnings Surprise (Based on analyst forecasts) & 124,373 & -0.0011 & 0.0004 & 0.0472 \\
Earnings Surprise (random walk) & 123,897 & -0.0006 & 0.0015 & 0.4960 \\
Earnings Surprise (random walk excluding special items) & 123,929 & 0.0001 & 0.0015 & 0.3899 \\
Change in forecast from t-90 to t & 124,441 & 0.4594 & 0.0100 & 29.7056 \\
Number of analyst forecasts used in analyst-based SUE & 124,423 & 5.2134 & 3.0000 & 5.0020 \\
Abnormal return $(-1,+1)$ & 124,438 & 0.0028 & 0.0021 & 0.0895 \\
Abnormal return $\left(\mathrm{t}_{1}+2, \mathrm{t}_{2}-1\right)$ & 124,441 & -0.0042 & -0.0006 & 0.2518 \\
Ohlson's O-score & 122,461 & 0.0023 & 0.0006 & 0.0048 \\
Campbell measure of distress & 122,055 & 0.0010 & 0.0004 & 0.0130 \\
Total assets $(\$ \mathrm{M})$ & 124,440 & $3,635.62$ & 522.37 & $18,380.71$ \\
Total sales $(\$ \mathrm{M})$ & 124,352 & 838.64 & 133.60 & $3,308.27$ \\
Market capitalization $(\$ \mathrm{M})$ & 124,441 & 4409.57 & 617.25 & $18,648.10$ \\
Return on assets & 124,441 & 0.0120 & 0.0137 & 0.0295 \\
\hline
\end{tabular}

Panel B: Non-Distressed Firms

\begin{tabular}{lllll}
\hline Variable & $\mathrm{N}$ & Mean & Median & Std Dev \\
\hline Earnings Surprise (Based on analyst forecasts) & 7,301 & -0.0021 & 0.0006 & 0.0796 \\
Earnings Surprise (random walk) & 7,281 & 0.0230 & 0.0017 & 0.3818 \\
Earnings Surprise (random walk excluding special items) & 7,281 & 0.0206 & 0.0017 & 0.3044 \\
Change in forecast from t-90 to t & 7,310 & 0.8447 & 0.0100 & 45.8891 \\
Number of analyst forecasts used in analyst-based SUE & 7,306 & 3.0872 & 2.0000 & 3.3830 \\
Abnormal return $(-1,+1)$ & 7,307 & -0.0025 & -0.0052 & 0.1104 \\
Abnormal return $\left(\mathrm{t}_{1}+2, \mathrm{t}_{2}-1\right)$ & 7,309 & -0.0022 & -0.0122 & 0.3925 \\
Ohlson's O-score & 7,310 & 0.4264 & 0.2482 & 0.3746 \\
Campbell measure of distress & 7,082 & 0.0260 & 0.0019 & 0.1159 \\
Total assets $(\$ \mathrm{M})$ & 7,310 & 420.63 & 75.86 & $2,933.94$ \\
Total sales $(\$ \mathrm{M})$ & 7,298 & 79.79 & 6.55 & 545.81 \\
Market capitalization $(\$ \mathrm{M})$ & 7,310 & 500.76 & 157.97 & $2,212.60$ \\
Return on assets & 7,310 & -0.1560 & -0.1292 & 0.1150 \\
\hline
\end{tabular}

We classify firms with Ohlson's O-scores greater than or equal to .038 as distressed. We classify observations with O-scores lower than .038 as non-distressed. We winsorize observations at the $1 \%$ and $99 \%$ levels, with the exception of the Campbell measure and the O-score. Total assets, sales, and book value of equity are the values at the end of the quarter. Panel A includes the summary statistics for firms classified as distressed. Panel B provides the summary statistics for the firms classified as non-distressed.

The summary statistics of our sample do not dramatically change when we divide our data into distressed and non-distressed firm observations based on the Campbell measure. Because this measure requires both additional accounting and market data, tests that include this variable have fewer observations. The Spearman and Pearson correlations between the Campbell and Ohlson measures are both greater than 0.5.

Table 2 reports the probability of distress in our sample. The proportion of distressed firms varies annually between $0.93 \%$ and $9.48 \%$. The proportion of distressed firms peaks during market downturns in 2002 and 2009. 
Table 2. Number of Distressed Firm Observations by Year

\begin{tabular}{|c|c|c|c|c|c|c|}
\hline \multirow{3}{*}{ Year } & \multicolumn{2}{|c|}{ Distressed firms } & \multicolumn{2}{|c|}{ Non-distressed firms } & \multirow{3}{*}{$\begin{array}{l}\text { \%Distressed } \\
\text { During Year }\end{array}$} & \multirow{3}{*}{$\begin{array}{l}\text { Total } \\
\text { Obs. }\end{array}$} \\
\hline & \# of Obs & $\%$ of Obs & $\#$ of $O \mathrm{hs}$ & $\%$ of Ohs & & \\
\hline & \# or UDs. & or ons. & \# or Uds. & \% OI UDS. & & \\
\hline 1989 & 32 & $0.44 \%$ & 2,633 & $2.12 \%$ & $1.20 \%$ & 2,665 \\
\hline 1990 & 22 & $0.30 \%$ & 2,354 & $1.89 \%$ & $0.93 \%$ & 2,376 \\
\hline 1991 & 50 & $0.68 \%$ & 2,354 & $1.89 \%$ & $2.08 \%$ & 2,404 \\
\hline 1992 & 67 & $0.92 \%$ & 2,595 & $2.09 \%$ & $2.52 \%$ & 2,662 \\
\hline 1993 & 111 & $1.52 \%$ & 2,818 & $2.26 \%$ & $3.79 \%$ & 2,929 \\
\hline 1994 & 203 & $2.78 \%$ & 4,502 & $3.62 \%$ & $4.31 \%$ & 4,705 \\
\hline 1995 & 178 & $2.44 \%$ & 4,196 & $3.37 \%$ & $4.07 \%$ & 4,374 \\
\hline 1996 & 229 & $3.13 \%$ & 5,243 & $4.21 \%$ & $4.18 \%$ & 5,472 \\
\hline 1997 & 372 & $5.09 \%$ & 5,922 & $4.76 \%$ & $5.91 \%$ & 6,294 \\
\hline 1998 & 468 & $6.40 \%$ & 6,924 & $5.56 \%$ & $6.33 \%$ & 7,392 \\
\hline 1999 & 485 & $6.63 \%$ & 7,079 & $5.69 \%$ & $6.41 \%$ & 7,564 \\
\hline 2000 & 413 & $5.65 \%$ & 5,839 & $4.69 \%$ & $6.61 \%$ & 6,252 \\
\hline 2001 & 533 & $7.29 \%$ & 6,175 & $4.96 \%$ & $7.95 \%$ & 6,708 \\
\hline 2002 & 669 & $9.15 \%$ & 6,389 & $5.13 \%$ & $9.48 \%$ & 7,058 \\
\hline 2003 & 424 & $5.80 \%$ & 6,394 & $5.14 \%$ & $6.22 \%$ & 6,818 \\
\hline 2004 & 348 & $4.76 \%$ & 6,979 & $5.61 \%$ & $4.75 \%$ & 7,327 \\
\hline 2005 & 376 & $5.14 \%$ & 7,190 & $5.78 \%$ & $4.97 \%$ & 7,566 \\
\hline 2006 & 399 & $5.46 \%$ & 7,241 & $5.82 \%$ & $5.22 \%$ & 7,640 \\
\hline 2007 & 422 & $5.77 \%$ & 7,144 & $5.74 \%$ & $5.58 \%$ & 7,566 \\
\hline 2008 & 394 & $5.39 \%$ & 7,202 & $5.79 \%$ & $5.19 \%$ & 7,596 \\
\hline 2009 & 624 & $8.54 \%$ & 6,834 & $5.49 \%$ & $8.37 \%$ & 7,458 \\
\hline 2010 & 344 & $4.71 \%$ & 7,077 & $5.69 \%$ & $4.64 \%$ & 7,421 \\
\hline 2011 & 147 & $2.01 \%$ & 3,357 & $2.7 \%$ & $4.20 \%$ & 3,504 \\
\hline Total & 7,310 & $100 \%$ & 124,441 & $100 \%$ & & 131,751 \\
\hline
\end{tabular}

We calculate Ohlson's O-score for each firm for each quarter. We define firm distress as an O-score greater than or equal to 0.038 . The numbers reported are the number of quarterly distressed observations in each calendar year. The percentage of observations for distressed and non-distressed firms represents the percentage of the distressed and non-distressed firm samples which occur in each calendar year respectively. \% Distressed During Year represents the percentage of distressed firms in the given calendar year. Total Obs. represents the total number of observations in the calendar year.

\section{Empirical Results}

\subsection{Earnings Management}

We first determine whether distressed firms manage earnings significantly more than non-distressed firms (H1). We use the method of Dechow, Sloan and Sweeney (1995) to calculate abnormal discretionary accruals. This measure of unsigned discretionary accruals is our dependent variable. In Table 3, we regress this variable on our measures of distress, control variables, and fixed effects. In the first model, we calculate distress using Ohlson's O-score. We find a significant and positive relationship between distress and unsigned discretionary accruals. The Campbell measure also has a significant and positive relationship with discretionary accruals. In the third model, we separate our sample into deciles based on $\mathrm{O}$-score and Campbell measures and use the top and bottom deciles. We identify distressed firms as those in the top decile of distress. We regress the absolute value of abnormal accruals on our distress measure. (Note 5) We find that firms in the top decile of firm distress have higher unsigned discretionary accruals. This result supports our first hypothesis. Managers of distressed firms manage earnings significantly more than managers of non-distressed firms. 
Table 3. Discretionary Accruals

Panel A: Unsigned Discretionary Accruals

\begin{tabular}{|c|c|c|c|}
\hline \multirow[b]{2}{*}{ Parameter } & \multicolumn{3}{|c|}{ Dependent Variable: |Discretionary Accruals| } \\
\hline & (1) & (2) & (3) \\
\hline \multirow[t]{2}{*}{ Intercept } & $0.1661 * * *$ & $0.1992 * * *$ & $0.1689 * * *$ \\
\hline & $(<.0001)$ & $(<.0001)$ & $(<.0001)$ \\
\hline \multirow[t]{2}{*}{ OSCORE } & $0.0790 * * *$ & & \\
\hline & $(<.0001)$ & & \\
\hline \multirow[t]{2}{*}{ CAMPBELL } & & $0.0590 * * *$ & \\
\hline & & $(<.0001)$ & \\
\hline \multirow[t]{2}{*}{ DIST } & & & $0.0111 * *$ \\
\hline & & & 0.0258 \\
\hline \multirow[t]{2}{*}{$\ln (\mathrm{TA})$} & $-0.0169 * * *$ & $-0.0193 * * *$ & $-0.0172 * * *$ \\
\hline & $(<.0001)$ & $(<.0001)$ & $(<.0001)$ \\
\hline \multirow[t]{2}{*}{ ROA } & $-0.1521 * * *$ & $-0.2395 * * *$ & $-0.2921 * * *$ \\
\hline & $(<.0001)$ & $(<.0001)$ & $(<.0001)$ \\
\hline Year Fix. Eff. & Yes & Yes & Yes \\
\hline Industry Fix. Eff. & Yes & Yes & Yes \\
\hline \# of Obs. & 84146 & 80574 & 84146 \\
\hline $\mathrm{R}^{2}$ & 0.0489 & 0.0498 & 0.0483 \\
\hline Distress Variable & Ohlson O-score & Campbell & O-score $($ cutoff $=.038)$ \\
\hline
\end{tabular}

Panel B: Signed Discretionary Accruals

\begin{tabular}{|c|c|c|c|c|}
\hline \multirow[b]{3}{*}{ Parameter } & \multicolumn{4}{|c|}{ Dependent Variable: Signed Discretionary Accruals } \\
\hline & \multicolumn{2}{|c|}{ Discretionary Accruals $>=0$} & \multicolumn{2}{|c|}{ Discretionary Accruals $<0$} \\
\hline & (1) & $(2)$ & (3) & (4) \\
\hline \multirow[t]{2}{*}{ Intercept } & $0.1605 * * *$ & $0.1412 * * *$ & $-0.1667 * * *$ & $-0.1519 * * *$ \\
\hline & $(<.0001)$ & $(0.0003)$ & $(<.0001)$ & $(0.0010)$ \\
\hline \multirow[t]{2}{*}{ O-score } & $0.1032 * * *$ & & $-0.0586 * * *$ & \\
\hline & $(<.0001)$ & & $(<.0001)$ & \\
\hline \multirow[t]{2}{*}{ Campbell } & & $0.3099 * * *$ & & $-0.2857 * * *$ \\
\hline & & $(<.0001)$ & & $(<.0001)$ \\
\hline \multirow[t]{2}{*}{$\ln (\mathrm{TA})$} & $-0.0165^{* * *}$ & $-0.0157 * * *$ & $0.0173 * * *$ & $0.0178 * * *$ \\
\hline & $(<.0001)$ & $<.0001$ & $(<.0001)$ & $(<.0001)$ \\
\hline \multirow[t]{2}{*}{ ROA } & $-0.1066^{* * *}$ & $-0.1528 * * *$ & $0.2147 * * *$ & $0.1807 * * *$ \\
\hline & $(0.0051)$ & $(<.0001)$ & $(<.0001)$ & $(<.0001)$ \\
\hline Year Fix. Eff. & Yes & Yes & Yes & Yes \\
\hline Industry Fix. Eff. & Yes & Yes & Yes & Yes \\
\hline \# of Obs. & 37,954 & 36,236 & 46,192 & 44,338 \\
\hline $\mathrm{R}^{2}$ & 0.1094 & 0.1167 & 0.0277 & 0.0287 \\
\hline Distress Variable & Ohlson O-score & Campbell & Ohlson O-score & Campbell \\
\hline
\end{tabular}


The dependent variable in this model is the absolute value of discretionary accruals as defined by Dechow, Sloan, and Sweeney (1995). O-score is defined as Ohlson's (1980) O-score. Campbell is defined as the value from Campbell et al. (2008) measure. When an observation is in the top decile of distress based on the distress measure used, DIST $=1$. DIST $=0$ for observations in the bottom decile of distress. DIST is an indicator variable where one indicates firm distress and zero equals a firm is non-distressed. We set the cutoff point at 0.038 . $\ln (\mathrm{TA})$ is the natural $\log$ of total assets. ROA is the net income of the firm divided by total assets. Distress Variable indicates the measure used to capture distress. Industry fixed effects are defined as the two-digit SIC code. Year fixed effects is defined as the calendar year in which the observation occurred. ***,**,* represent significance at the $1 \%, 5 \%$, and $10 \%$ level, respectively.

We find a significant and negative relation between firm profitability (net income / total assets) and the absolute value of the firm's discretionary accruals. Managers of profitable firms have less need to manage earnings while managers of distressed firms have stronger incentives to meet earnings expectations. We find that the coefficient on firm size, measured by $\ln (\mathrm{TA})$, is negative and significantly related to unsigned discretionary accruals.

Making the distinction between positive and negative discretionary accruals is important in this context because firms in distress often write off significantly more fixed assets and accounts receivable than non-distressed firms. Saleh and Ahmed (2007) find that distressed firms write off significantly more fixed assets than non-distressed firms during post-default debt renegotiations with lenders. By understating the value of fixed assets, managers of these firms strengthen their bargaining position. Writing off older accounts receivable as uncollectable improves the days sales outstanding of accounts receivable relative to industry competitors. This action could help the firm when applying for a loan.

Our results remain unchanged when we use annual earnings announcement surprises instead of quarterly earnings announcement surprises. Distressed firms have significantly larger absolute changes in discretionary accruals after a negative annual earnings surprise. The significance is persistent regardless of our measure of earnings surprise, distress, or control variables.

In Panel B of Table 3 we examine the relationship between signed discretionary accruals and firm distress. We separate our observations into both positive and negative signed discretionary accruals. Then we regress signed discretionary accruals on firm distress and the control variables.

The first two models show the relationship between firm distress and positive discretionary accruals. The coefficient on our O-score variable in the first model is positive and significant, indicating that distressed firms manage earnings upward to a greater degree than non-distressed firms. The second model shows a positive relationship between the Campbell measure of firm distress and positive discretionary accruals. This finding indicates that our results are robust to several measures of firm distress.

In the third and fourth models, we regress negative discretionary accruals on firm distress and the control variables. In the third model, we find a negative and significant relationship between $\mathrm{O}$-score and discretionary accruals. In the fourth model, we find the same relationship between the Campbell measure of distress and discretionary accruals. These results indicate that distressed firms manage earnings downward significantly more than non-distressed firms.

There are at least two explanations for why distressed firms manage earnings upwards. Distressed firms might simply be reporting accruals that went previously unreported. When distressed firms manage earnings downward in one quarter, they must eventually report those earnings. However, with distressed firms, a significant portion of negative discretionary accruals comes from assets being written off. Assets that are written off do not have to be reported in future periods. These firms might also manage earnings upward in order to avoid failing to meet analyst expectations.

To test whether managers of distressed firms manage earnings upward to avoid missing consecutive earnings targets, we examine the behavior of firms in the quarter after they miss analyst earnings expectations. Table 4 provides our results. We regress signed discretionary accruals on firm distress, controls, and fixed effects.

Our variable of interest in all models is DIST. DIST is an indicator variable which equals one if the O-score of the firm is greater than or equal to 0.038 and zero otherwise. We find a positive and significant relationship between DIST and signed discretionary accruals in the period after firms miss earnings surprises. This finding indicates that distressed firms inflate earnings more than non-distressed firms after they fail to meet analyst expectations.

In some cases, such as when the manager believes that the firm will fail in the near future, it is in the manager's best interest to manage earnings downward. This action improves the bargaining position of the firm's manager when the firm enters bankruptcy. We note this divergence in our sample. We test this divergence in Table 4 by creating a 
variable called MISS and examining the interaction between this variable and DIST. MISS is an indicator variable that equals one if the firm fails to meet the next quarterly earnings expectations and zero otherwise. The interaction between DIST and MISS indicates whether distressed firms that miss two consecutive earnings forecasts in a row manage earnings upward or downward. In all cases, the coefficient on the interaction term is negative and the distressed firms that consistently fail to meet earnings expectations draw down assets in anticipation of bankruptcy.

Table 4. Discretionary Accruals after Earnings Surprises

Dependent Variable: Signed Discretionary Accruals

\begin{tabular}{|c|c|c|c|c|c|c|}
\hline & (1) & (2) & (3) & (4) & (5) & (6) \\
\hline \multirow[t]{2}{*}{ Intercept } & 0.0880 & 0.0834 & 0.0833 & $0.0121 * * *$ & -0.0009 & -0.0010 \\
\hline & (0.1099) & $(0.1287)$ & $(0.1290)$ & $(0.0023)$ & $(0.5316)$ & (0.5019) \\
\hline \multirow[t]{2}{*}{ DIST } & $0.0162 * *$ & $0.0172 * *$ & $0.0178 * *$ & $0.0212 * * *$ & $0.0240 * * *$ & $0.0246^{* * *}$ \\
\hline & $(0.0210)$ & $(0.0137)$ & $(0.0107)$ & $(0.0031)$ & $(0.0007)$ & $(0.0005)$ \\
\hline \multirow[t]{2}{*}{ DIST*MISS } & $-0.0226 * * *$ & $-0.0226 * * *$ & $-0.0239 * * *$ & $-0.0246 * * *$ & $-0.0331 * *$ & $-0.0257 * * *$ \\
\hline & $(0.0047)$ & $(0.0047)$ & $(0.0028)$ & $(0.0027)$ & $(0.0344)$ & $(0.0017)$ \\
\hline \multirow[t]{2}{*}{ MISS } & $0.0364 * *$ & $0.0361 * *$ & & $0.0341 * *$ & $0.0246^{*}$ & \\
\hline & $(0.0174)$ & $(0.0183)$ & & $(0.0291)$ & $(0.0027)$ & \\
\hline \multirow[t]{2}{*}{$\ln (\mathrm{TA})$} & -0.0008 & & & $-0.0021 * * *$ & & \\
\hline & $(0.2228)$ & & & $(0.0004)$ & & \\
\hline \multirow[t]{2}{*}{ ROA } & $0.1980 * * *$ & $0.1954 * * *$ & $0.1959 * * *$ & $0.1674 * * *$ & $0.1606^{* * *}$ & $0.1609 * * *$ \\
\hline & $(<.0001)$ & $(<.0001)$ & $(<.0001)$ & $(<.0001)$ & $(<.0001)$ & $(<.0001)$ \\
\hline \multirow[t]{2}{*}{$\mathrm{B} / \mathrm{M}$} & $-0.0065^{* * *}$ & $-0.0066 * * *$ & $-0.0067 * * *$ & $-0.0067 * * *$ & $-0.0071 * * *$ & $-0.0072 * * *$ \\
\hline & $(<.0001)$ & $(<.0001)$ & $(<.0001)$ & $(<.0001)$ & $(<.0001)$ & $(<.0001)$ \\
\hline Year Fix. Eff. & Yes & Yes & Yes & No & No & No \\
\hline Industry Fix. Eff. & Yes & Yes & Yes & No & No & No \\
\hline \# of Obs. & 26,400 & 26,400 & 26,400 & 26,400 & 26,400 & 26,400 \\
\hline $\mathrm{R}^{2}$ & 0.0566 & 0.0566 & 0.0564 & 0.0039 & 0.0034 & 0.0033 \\
\hline
\end{tabular}

The dependent variable is value of signed discretionary accruals. We use Ohlson's O-score to calculate distress. Firms with O-scores greater than or equal to .038 are distressed (DIST=1). All other firms are non-distressed (DIST=0). MISS is an indicator which represents whether the firm missed the quarterly earnings target in the quarter. MISS $=1$ indicates that the firm missed the earnings target in the current quarter. MISS $=0$ indicates that the firm met or exceeded earnings expectations in the given quarter. DIST*MISS $=1$ if the firm is both distressed and missed earnings expectations in the current quarter. $\ln (\mathrm{TA})$ represents the natural $\log$ of total assets of the firm. ROA is net income scaled by total assets. Distress Variable indicates the measure used to calculate distress. ***, **, * represent significance at the $1 \%, 5 \%$, and $10 \%$ level, respectively.

Our analysis supports the idea that managers of distressed firms are significantly more likely to use discretionary accruals. Our evidence indicates that distressed firms manage earnings significantly higher than do non-distressed firms in the quarter after a negative earnings surprise. Managers of distressed firms appear to be more concerned than managers of non-distressed firms about underperforming analyst expectations.

\subsection{Earnings Surprises}

\subsubsection{Magnitude of the Investor Response}

Assuming investors can detect earnings management, the willingness of firms to manage earnings should lead investors to discount earnings reports. The natural reaction to skepticism concerning earnings quality would be a weaker response to an announcement. 
Because managers of distressed firms manage earnings to a greater extent, it seems reasonable to conjecture that this would lead to a weaker investor response. In Table 5, we test this hypothesis. The size of the earnings surprise is significant and positively associated with the magnitude of the abnormal return.

The coefficient on DIST*SUE is significant and negative in all specifications. This finding indicates that investors are less sensitive to earnings surprises of distressed firms than to the earnings surprises of non-distressed firms. The relation between distress and abnormal returns remains unchanged regardless of our measure of distress. Our results are also unchanged when we use the random walk measure of earnings surprise both including and excluding special items. This finding supports our hypothesis that investors are less responsive to earnings surprises of distressed firms.

Table 5. Distressed Firms versus Non-Distressed Firms

\begin{tabular}{|c|c|c|c|c|}
\hline \multirow[b]{2}{*}{ Parameter } & \multicolumn{4}{|c|}{ Dependent variable: Abnormal return $(-1,+1)$} \\
\hline & (1) & (2) & (3) & (4) \\
\hline \multirow[t]{2}{*}{ Intercept } & $0.1136^{* * * *}$ & -0.0021 & $0.0807 * *$ & 0.0016 \\
\hline & $(0.0027)$ & $(0.2247)$ & $(0.0365)$ & $(0.3421)$ \\
\hline \multirow[t]{2}{*}{ DIST } & 0.0022 & 0.0022 & -0.0021 & -0.0021 \\
\hline & $(0.2733)$ & $(0.2708)$ & $(0.2966)$ & $(0.2833)$ \\
\hline \multirow[t]{2}{*}{ SUE } & $2.1491 * * *$ & $2.1635^{* * *}$ & & \\
\hline & $(<.0001)$ & $(<.0001)$ & & \\
\hline \multirow[t]{2}{*}{ SUE_WALK } & & & $0.2242 * * *$ & $0.2131 * * *$ \\
\hline & & & $(<.0001)$ & $(<.0001)$ \\
\hline \multirow[t]{2}{*}{ DIST*SUE } & $-2.0586 * * *$ & $-2.0808 * * *$ & & \\
\hline & $(<.0001)$ & $(<.0001)$ & & \\
\hline \multirow[t]{2}{*}{ DIST*SUE_WALK } & & & $-0.2195 * * *$ & $-0.2095 * * *$ \\
\hline & & & $(<.0001)$ & $(<.0001)$ \\
\hline \multirow[t]{2}{*}{ CHFORCAST } & -0.0014 & -0.0009 & -0.0027 & -0.0026 \\
\hline & $(0.6861)$ & $(0.7996)$ & $(0.4363)$ & $(0.4663)$ \\
\hline \multirow[t]{2}{*}{ CHFORCAST*DIST } & 0.0013 & 0.0007 & 0.0026 & 0.0024 \\
\hline & $(0.7187)$ & $(0.8330)$ & $(0.4642)$ & $(0.4955)$ \\
\hline \multirow[t]{2}{*}{ NUMEST } & -0.0004 & -0.0003 & $-0.0005^{*}$ & -0.0005 \\
\hline & $(0.1922)$ & $(0.3037)$ & $(0.0864)$ & $(0.1288)$ \\
\hline Year Fix. Eff. & Yes & No & Yes & No \\
\hline Industry Fix. Eff. & Yes & No & Yes & No \\
\hline \# of Obs. & 11368 & 11368 & 11920 & 11920 \\
\hline $\mathrm{R}^{2}$ & 0.0250 & 0.0164 & 0.0150 & 0.0058 \\
\hline Distress Variable & \multicolumn{4}{|c|}{ O-Score (Cutoff point of .038) } \\
\hline
\end{tabular}

The dependent variable in all cases is the abnormal return around the earnings announcement. We calculate abnormal returns using the Fama-French 3 -factor model and a $(-1,1)$ interval. Our dependent variable is the abnormal return in the three days around the earnings surprise. DIST is an indicator variable for distress. DIST $=1$ if Ohlson's O-score is greater than or equal to 0.038 . DIST $=0$ otherwise. SUE is the standardized unexpected earnings based on analyst the mean analyst expectation. SUE_WALK is the earnings surprise based on 4-quarter lagged earnings. DIST*SUE is the interaction between DIST and SUE. DIST*SUE_WALK is the interaction between DIST and SUE_WALK. CHFORCAST is the difference between the first and the last analyst forecast. When there is only one forecast, CHFORCAST $=0$. CHFORCASTDIST is an interaction variable between DIST and CHFORCAST. NUMEST is a count of the number of analyst estimates of the quarterly earnings for the quarter in 
question. Total assets are total book assets. Distress Variable measures distress. ***, **, * represent significance at the $1 \%, 5 \%$, and $10 \%$ level, respectively.

Our measure of information asymmetry is negatively related to abnormal returns in all of our models, although it is not significant in the reported tests. We also find that changes in analyst forecasts over time are negatively related to abnormal returns, consistent with Bartov, Givoly, and Hayn (2002). The $\mathrm{R}^{2}$ associated with these regressions are comparable to regressions from previous studies.

\subsubsection{Differences in the Sign of the Response}

Next we examine whether the investor reaction to positive or negative earnings surprises is larger for distressed firms. Previous studies find that in broad samples, the investor response to negative earnings surprises is significantly larger than that to positive surprises. To test whether this is the case for distressed firms, we divide our distressed firms based on the sign of the earnings surprise. Table 6 provides the results. In Panel A, we include only firm observations that did not meet earnings expectations. We regress abnormal returns on the distress variable and several controls. The returns of distressed firms are significantly more positive than those of non-distressed firms. Investors do not respond as negatively to distressed firms that do not meet analyst forecasts.

In Panel B, we include only observations where the firm meets or exceeds analyst expectations. We find that distressed firms have significantly lower abnormal returns. This finding indicates that investors are less sensitive to positive earnings surprises of distressed firms than the positive earnings surprises of non-distressed firms. The results support Hypothesis 4. Investors are less sensitive to the earnings surprises of distressed firms.

Table 6. Differences in the Investor Response to Earnings Surprises of Distressed and Non-Distressed Firms

Panel A: Firms That Do Not Meet Earnings Expectations

\begin{tabular}{lllll}
\hline \multicolumn{5}{l}{ Dependent Variable: Abnormal Return $(-1,+1)$} \\
\hline Parameter & $(1)$ & $(2)$ & $(3)$ & $(4)$ \\
Intercept & -0.0193 & -0.0192 & -0.0191 & $-.0267^{* * *}$ \\
& $(0.2250$ & $(0.2266)$ & $(0.2291)$ & $(<.0001)$ \\
DIST & $0.0096^{* * *}$ & $0.0095^{* * *}$ & $0.0095^{* * *}$ & $0.0077^{* * *}$ \\
& $(<.0001)$ & $(<.0001)$ & $(<.0001)$ & $(<.0001)$ \\
SUE & $0.4138^{* * *}$ & $0.4160^{* * *}$ & $0.4173^{* * *}$ & $0.4267^{* * *}$ \\
& $(<.0001)$ & $(<.0001)$ & $(<.0001)$ & $(<.0001)$ \\
CHFORCAST & $0.0000^{* * *}$ & & & $0.0000^{* * *}$ \\
& $(0.0007)$ & & & $(.0008)$ \\
NUMEST & 0.0000 & 0.0000 & & 0.0000 \\
& $(0.7958)$ & $(0.8384)$ & & $(.8836)$ \\
Year Fix. Eff. & Yes & Yes & Yes & No \\
Industry Fix. Eff. & Yes & Yes & Yes & No \\
\# of Obs. & 38852 & 38852 & 38852 & 38852 \\
$\mathrm{R}^{2}$ & 0.0241 & 0.0238 & 0.0238 & 0.0041 \\
Distress Variable & OSCORE (Cutoff point of .038) & & \\
\hline
\end{tabular}


Panel B: Firms That Meet Earnings Expectations

\begin{tabular}{|c|c|c|c|c|}
\hline \multicolumn{5}{|c|}{ Dependent Variable Abnormal Return $(-1,+1)$} \\
\hline Parameter & (1) & (2) & (3) & (4) \\
\hline \multirow[t]{2}{*}{ Intercept } & $0.0175^{*}$ & $0.0175^{*}$ & 0.0169 & $0.0106 * * *$ \\
\hline & $(0.0956)$ & $(0.0956)$ & $(0.1077)$ & $(<.0001)$ \\
\hline \multirow[t]{2}{*}{ DIST } & $-0.0170 * * *$ & $-0.0170 * * *$ & $-0.0168 * * *$ & $-0.0186 * * *$ \\
\hline & $(<.0001)$ & $(<.0001)$ & $(<.0001)$ & $(<.0001)$ \\
\hline \multirow[t]{2}{*}{ SUE } & $2.4355 * * *$ & $2.4354 * * *$ & $2.4528 * * *$ & $2.3949 * * *$ \\
\hline & $(<.0001)$ & $(<.0001)$ & $(<.0001)$ & $(<.0001)$ \\
\hline \multirow[t]{2}{*}{ CHFORCAST } & 0.0000 & & & 0.0000 \\
\hline & $(0.6181)$ & & & $(0.7969)$ \\
\hline \multirow[t]{2}{*}{ NUMEST } & $-0.0001 *$ & $-0.0001 *$ & & $-0.0002 * * *$ \\
\hline & $(0.0639)$ & $(0.0634)$ & & $(0.0014)$ \\
\hline Year Fix. Eff. & YES & YES & YES & NO \\
\hline Industry Fix. Eff. & YES & YES & YES & NO \\
\hline \# of Obs. & 90836 & 90836 & 90836 & 90836 \\
\hline $\mathrm{R}^{2}$ & 0.0282 & 0.0282 & 0.0282 & 0.0243 \\
\hline Distress variable & \multicolumn{4}{|c|}{ O-score (Cutoff point of .038) } \\
\hline
\end{tabular}

Our dependent variable is the abnormal return in the three days around the earnings surprise. DIST=1 if the observation is classified as distressed. Distress Variable measures firm distress. If Ohlson's O-score is greater than or equal to 0.038 then DIST $=1$. Otherwise, DIST $=0$. SUE is the analyst-based earnings surprised. CHFORCAST is the change between the first and last forecast in the 90 days prior to the earnings announcement. NUMEST is the number of analysts who provided earnings forecasts. ***, **, * represent significance at the $1 \%, 5 \%$, and $10 \%$ level, respectively.

In order to confirm the results from Table 6, we provide an additional test of the investor response to positive and negative earnings surprise. Table 7 presents our findings. In Panel A, we restrict our sample to distressed firm observations. The variable of interest in this table is MEET. We find that for distressed firms, MEET is marginally positively related to the absolute value of cumulative abnormal returns. This finding indicates that investors are more responsive to the positive earnings surprises of distressed firms than to the negative earnings surprises of distressed firms. This result supports the bankruptcy avoidance effect: as firms approach bankruptcy, positive news is rewarded more strongly than negative news. Our results are robust to the Altman Z-score and Campbell measures of distress (Altman 1968) and are significant after controlling for year and industry fixed effects. The use of different return windows does not change our results. 
Table 7. Meeting and Beating Earnings Expectations

Panel A: Distressed Firms

\begin{tabular}{|c|c|c|c|c|c|c|}
\hline \multicolumn{7}{|c|}{ Dependent Variable: |Cumulative abnormal return $(-1,+1) \mid$} \\
\hline Parameter & (1) & (2) & (3) & (4) & (5) & (6) \\
\hline \multirow[t]{2}{*}{ Intercept } & 0.0375 & $0.0443^{* * *}$ & $0.0591 * * *$ & 0.0613 & $0.0517 * * *$ & $0.075 * * *$ \\
\hline & $(0.2391)$ & $(<.0001)$ & $(<.0001)$ & $(0.5127)$ & $(<.0001)$ & $(<.0001)$ \\
\hline \multirow[t]{2}{*}{$\mathrm{ABS}(\mathrm{SUE})$} & $0.6290 * * *$ & $0.6934 * * *$ & $0.7193^{* * *}$ & $0.7796 * * *$ & $0.771 * * *$ & $0.8132 * * *$ \\
\hline & $(<.0001)$ & $(<.0001)$ & $(<.0001)$ & $(<.0001)$ & $(<.0001)$ & $(<.0001)$ \\
\hline \multirow[t]{2}{*}{ MEET } & 0.0004 & 0.0015 & $0.0037^{*}$ & 0.0028 & $0.0031^{*}$ & $0.0057 * * *$ \\
\hline & $(0.8390)$ & $(0.4451)$ & $(0.0559)$ & $(0.1325)$ & $(0.0879)$ & $(0.0018)$ \\
\hline \multirow[t]{2}{*}{ NUMEST } & $0.0008 * * *$ & $0.0009 * * *$ & $0.0012 * * *$ & $0.0007 * * *$ & $0.0008 * * *$ & $0.0015^{* * *}$ \\
\hline & $(0.0030)$ & $(0.0013)$ & $(<.0001)$ & $(0.0002)$ & $(<.0001)$ & $(<.0001)$ \\
\hline \multirow[t]{2}{*}{ CHFOR } & $0.0001 * * *$ & $0.0001 * * *$ & $0.0001 * * *$ & $0.0001 * * *$ & $0.0001 * * *$ & $0.0001 * * *$ \\
\hline & $(<.0001)$ & $(<.0001)$ & $(<.0001)$ & $(0.0002)$ & $(0.0011)$ & $(0.0004)$ \\
\hline \multirow[t]{2}{*}{ ROA } & $-0.0151^{*}$ & $-0.0161 * *$ & $-0.0238 * * *$ & $0.0268 * * *$ & $0.0339 * * *$ & $0.0308 * * *$ \\
\hline & $(0.0638)$ & $(0.0468)$ & $(0.0031)$ & $(0.0005)$ & $(<.0001)$ & $(<.0001)$ \\
\hline Year Fix. Eff. & Yes & Yes & No & Yes & Yes & No \\
\hline Industry Fix. Eff. & Yes & No & No & Yes & No & No \\
\hline \# of Obs. & 7298 & 7298 & 7298 & 12786 & 12786 & 12786 \\
\hline $\mathrm{R}^{2}$ & 0.0768 & 0.0506 & 0.0236 & 0.0613 & 0.0478 & 0.0218 \\
\hline Distress Variable & \multicolumn{3}{|c|}{ O-score $>0.038$} & \multicolumn{3}{|c|}{ Campbell top decile } \\
\hline
\end{tabular}

Panel B: Non-distressed Firms

\begin{tabular}{|c|c|c|c|c|c|c|}
\hline \multirow[b]{2}{*}{ Parameter } & \multicolumn{6}{|c|}{ Dependent Variable: |Cumulative abnormal return $(-1,+1) \mid$} \\
\hline & (1) & (2) & (3) & (4) & (5) & (6) \\
\hline \multirow[t]{2}{*}{ Intercept } & $0.0693 * * *$ & $0.0575 * * *$ & $0.0581 * * *$ & $0.0522 * * *$ & $0.0592 * * *$ & $0.0550 * * *$ \\
\hline & $(<.0001)$ & $(<.0001)$ & $(<.0001)$ & $(0.0003)$ & $(<.0001)$ & $(<.0001)$ \\
\hline \multirow[t]{2}{*}{ ABS(SUE) } & $1.1608 * * *$ & $1.1589 * * *$ & $1.2093 * * *$ & $1.1458 * * *$ & $1.1882 * * *$ & $1.2757 * * *$ \\
\hline & $(<.0001)$ & $(<.0001)$ & $(<.0001)$ & $(<.0001)$ & $(<.0001)$ & $(<.0001)$ \\
\hline \multirow[t]{2}{*}{ MEET } & $-0.0030 * * *$ & $-0.0016 * * *$ & $0.0011 * * *$ & $-0.0061 * * *$ & $-0.0043 * * *$ & $-0.0022^{*}$ \\
\hline & $(<.0001)$ & $(<.0001)$ & $(0.0098)$ & $(<.0001)$ & $(<.0001)$ & $(0.0523)$ \\
\hline \multirow[t]{2}{*}{ NUMEST } & $-0.0004 * * *$ & $-0.0005 * * *$ & $-0.0004 * * *$ & $-0.0005^{* * *}$ & $-0.0005 * * *$ & $-0.0003 * * *$ \\
\hline & $(<.0001)$ & $(<.0001)$ & $(<.0001)$ & $(<.0001)$ & $(<.0001)$ & $(<.0001)$ \\
\hline \multirow[t]{2}{*}{ CHFOR } & 0.0000 & 0.0000 & 0.0000 & -0.0051 & $-0.0139 * * *$ & $-0.0122 * * *$ \\
\hline & $(0.7978)$ & $(0.2928)$ & $(0.2180)$ & $(0.1738)$ & $(0.0001)$ & $(0.0009)$ \\
\hline \multirow[t]{2}{*}{ ROA } & -0.0094 & -0.0087 & $-0.0390 * * *$ & 0.0209 & 0.0050 & $-0.0310 * *$ \\
\hline & $(0.1546)$ & $(0.1890)$ & $(<.0001)$ & $(0.1797)$ & $(0.7489)$ & $(0.0470)$ \\
\hline Year Fix. Eff. & Yes & Yes & No & Yes & Yes & No \\
\hline Industry Fix. Eff. & Yes & No & No & Yes & No & No \\
\hline \# of Obs. & 122390 & 122390 & 122390 & 12788 & 12788 & 12788 \\
\hline $\mathrm{R}^{2}$ & 0.0820 & 0.0573 & 0.0274 & 0.0807 & 0.0545 & 0.0205 \\
\hline Distress Variable & \multicolumn{3}{|c|}{ O-score (Cutoff point of .038) } & \multicolumn{3}{|c|}{ Campbell bottom decile } \\
\hline
\end{tabular}


We examine the impact of meeting or beating earnings expectations. The dependent variable is the absolute value of the abnormal return from $(-1,+1)$ days around the earnings announcement. ABS(SUE) is the absolute value of the earnings surprise based on analyst expectations. MEET $=1$ if the firm met or exceeded earnings expectations and MEET $=0$ otherwise. MEET is our variable of interest. Distress Variable indicates the measure of distress used. ***, $* *, *$ represent significance at the $1 \%, 5 \%$, and $10 \%$ level, respectively.

The signs of our control variables are consistent with previous research. The absolute value of the earnings surprise is significant and positively related to the absolute value of the abnormal return. This result indicates that investors have larger responses to larger earnings surprises. The change in analyst forecasts during the quarter is positively related to the absolute value of the abnormal returns. This finding is consistent with Bartov et al. (2002).

In Panel B, we examine the abnormal return around the positive and negative earnings surprises of non-distressed firms. We find that the investor response to negative earnings surprises is significantly stronger than the response to positive earnings surprises. The earnings management effect dominates the bankruptcy avoidance effect for non-distressed firms. The results in Panel B are consistent with the findings of Dellavigna and Pollet (2009) and Michaely, Thaler, and Womack (1995). Our results indicate that investors view distressed and non-distressed firms differently.

Table 8 provides additional support for the bankruptcy avoidance effect. We regress the change in the O-score calculation from previous quarter to the current quarter on an indicator variable for whether the earnings surprise is negative. We include control variables and fixed effects in our model. We find a significant and negative relation between the interaction variable (NEG*DIST) and the increase in bankruptcy probability. This finding indicates that distressed firms that fail to meet earnings expectations in the previous quarter have significantly larger increases in default probability than non-distressed firms.

Table 8. Change in Bankruptcy Probability after Earnings Surprises

\begin{tabular}{|c|c|c|c|c|c|c|}
\hline \multicolumn{7}{|c|}{ Dependent variable: $\mathrm{O}$-score minus $\mathrm{O}$-score in the previous quarter } \\
\hline Parameter & (1) & (2) & (3) & (4) & (5) & (6) \\
\hline \multirow[t]{2}{*}{ Intercept } & 0.0184 & $0.0348 * * *$ & $0.0353 * * *$ & -0.0060 & $-0.0127 * * *$ & $-0.0097 * * *$ \\
\hline & $(0.1908)$ & $(<.0001)$ & $(<.0001)$ & $(0.7799)$ & $(<.0001)$ & $(<.0001)$ \\
\hline \multirow[t]{2}{*}{$\mathrm{NEG}_{\mathrm{t}-1}$} & $-0.0047 * * *$ & $-0.0046 * * *$ & $-0.0037 * * *$ & $-0.0046^{* * *}$ & $-0.0052 * * *$ & $-0.0043 * * *$ \\
\hline & $(<.0001)$ & $(<.0001)$ & $(<.0001)$ & $(<.0001)$ & $(<.0001)$ & $(<.0001)$ \\
\hline \multirow[t]{2}{*}{$\operatorname{DIST}_{\mathrm{t}-1}$} & $-0.2978 * * *$ & $-0.2979 * * *$ & $-0.2987 * * *$ & $-0.1012 * * *$ & $-0.1013 * * *$ & $-0.1004 * * *$ \\
\hline & $(<.0001)$ & $(<.0001)$ & $(<.0001)$ & $(<.0001)$ & $(<.0001)$ & $(<.0001)$ \\
\hline \multirow[t]{2}{*}{$\mathrm{NEG}_{\mathrm{t}-1} * \mathrm{DIST}_{\mathrm{t}-1}$} & $0.0418 * * *$ & $0.0420 * * *$ & $0.0419 * * *$ & $0.0201 * * *$ & $0.0202 * * *$ & $0.0197 * * *$ \\
\hline & $(<.0001)$ & $(<.0001)$ & $(<.0001)$ & $(<.0001)$ & $(<.0001)$ & $(<.0001)$ \\
\hline \multirow[t]{2}{*}{$\ln (\mathrm{TA})$} & $-0.0018 * * *$ & $-0.0014 * * *$ & $-0.0018 * * *$ & $0.0036^{* * *}$ & $0.0034 * * *$ & $0.0029 * * *$ \\
\hline & $(<.0001)$ & $(<.0001)$ & $(<.0001)$ & $(<.0001)$ & $(<.0001)$ & $(<.0001)$ \\
\hline \multirow[t]{2}{*}{$\mathrm{B} / \mathrm{M}$} & $-0.0127 * * *$ & $-0.0124 * * *$ & $-0.0130 * * *$ & 0.0011 & $0.0032 * * *$ & $0.0031 * * *$ \\
\hline & $(<.0001)$ & $(<.0001)$ & $(<.0001)$ & $(0.1664)$ & $(<.0001)$ & $(<.0001)$ \\
\hline \multirow[t]{2}{*}{ NUMEST } & $0.0004 * * *$ & $0.0004 * * *$ & $0.0004 * * *$ & 0.0001 & $0.0002 *$ & $0.0002 *$ \\
\hline & $(<.0001)$ & $(<.0001)$ & $(<.0001)$ & $(0.1690)$ & $(0.0557)$ & $(0.0720)$ \\
\hline \multirow[t]{2}{*}{ ROA } & $-1.2308 * * *$ & $-1.2241 * * *$ & $-1.2132 * * *$ & $-0.9314 * * *$ & $-0.9013 * * *$ & $-0.8852 * * *$ \\
\hline & $(<.0001)$ & $(<.0001)$ & $(<.0001)$ & $(<.0001)$ & $(<.0001)$ & $(<.0001)$ \\
\hline Year Fix. Eff. & Yes & Yes & No & Yes & Yes & No \\
\hline Industry Fix. Eff. & Yes & No & No & Yes & No & No \\
\hline \# of Obs. & 72154 & 72154 & 72154 & 71013 & 71013 & 71013 \\
\hline $\mathrm{R}^{2}$ & 0.3483 & 0.3471 & 0.3454 & 0.1684 & 0.1636 & 0.1603 \\
\hline Distress Variable & \multicolumn{3}{|c|}{ O-score (Cutoff point of .038) } & \multicolumn{3}{|c|}{ Campbell bottom decile } \\
\hline
\end{tabular}


In this table, we examine the change in bankruptcy probability after an earnings surprise. The dependent variable in the table is the difference between the calculated Ohlson's O-score in the current quarter and the O-score in the prior quarter. $\mathrm{SUE}_{\mathrm{t}-1}$ is the earnings surprise in the prior quarter. DIST $\mathrm{t}_{\mathrm{t}-1}$ indicates whether the firm was classified as distressed based on an $\mathrm{O}$-score greater than .038 in the previous quarter. $\mathrm{SUE}_{\mathrm{t}-1} * \mathrm{DIST}_{\mathrm{t}-1}$ is the interaction between SUE and DIST. $\ln (\mathrm{TA})$ represents the natural $\log$ of total assets of the firm. B/M is the book-to-market ratio. NUMEST is the number of analysts who provided earnings forecasts. ***, **, * represent significance at the $1 \%, 5 \%$, and $10 \%$ level, respectively.

\subsection{Post-Earnings Announcement Drift}

In Table 9, we examine the relation between firm distress and post-earnings announcement drift. Because distressed firms are characterized by less analyst coverage and fewer investors, it might be argued that the information diffusion is slower for these firms. To examine this conjecture, we examine the post-earnings announcement drift of the firms in our sample. We use the same variable of interest and control variables as we did in Table 5.

We find that the coefficient on the interaction term between our earnings surprise and distress variables is significantly negative. This finding indicates that once we control for factors such as size and analyst coverage, distressed firms have significantly less post-earnings announcement drift. An explanation of this result is that earnings reports of distressed firms have less information content.

In additional tests, we also find that the bankruptcy avoidance effect is present over the quarter following an earnings announcement. (Note 6) Our analysis indicates that distressed firms that exceed earnings expectations have larger-in-magnitude investor responses over the next quarter.

Table 9. Post-Earnings Announcement Drift

\begin{tabular}{|c|c|c|c|c|}
\hline Parameter & (1) & (2) & (3) & (4) \\
\hline \multirow[t]{2}{*}{ Intercept } & 0.0169 & 0.0169 & 0.0387 & 0.0387 \\
\hline & $(0.8846)$ & $(0.8846)$ & $(0.7393)$ & $(0.7391)$ \\
\hline \multirow[t]{2}{*}{ DIST } & 0.0040 & 0.0040 & -0.0061 & -0.0061 \\
\hline & $(0.5122$ & $(0.5095)$ & $(0.3066)$ & $(0.3022)$ \\
\hline \multirow[t]{2}{*}{ SUE } & $3.6110 * * *$ & $3.6112 * * *$ & & \\
\hline & $(<.0001)$ & $(<.0001)$ & & \\
\hline \multirow[t]{2}{*}{ SUE_WALK } & & & $0.3057 *$ & $0.3053^{*}$ \\
\hline & & & $(0.0503)$ & $(0.0505)$ \\
\hline \multirow[t]{2}{*}{ DIST*SUE } & $-2.7797 * * *$ & $-2.7799 * * *$ & & \\
\hline & $(<.0001)$ & $(<.0001)$ & & \\
\hline \multirow[t]{2}{*}{ DIST*SUE_WALK } & & & -0.1475 & -0.1472 \\
\hline & & & $(0.3565)$ & $(0.3574)$ \\
\hline \multirow[t]{2}{*}{ CHFORCAST } & -0.0005 & $-0.0002 * *$ & 0.0007 & $-0.0002 * * *$ \\
\hline & $(0.9603)$ & $(0.0161)$ & $(0.9441)$ & $(0.0045)$ \\
\hline \multirow[t]{2}{*}{ CHFORCAST $*$ DIST } & 0.0003 & & -0.0010 & \\
\hline & $(0.9750)$ & & $(0.9262)$ & \\
\hline \multirow[t]{2}{*}{ NUMEST } & $-0.0027 * * *$ & $-0.0027 * * *$ & $-0.0018^{*}$ & $-0.0018^{*}$ \\
\hline & $(0.0061)$ & $(0.0061)$ & $(0.0606)$ & $(0.0607)$ \\
\hline Year Fix. Eff. & Yes & Yes & Yes & Yes \\
\hline Industry Fix. Eff. & Yes & Yes & Yes & Yes \\
\hline \# of Obs. & 11,368 & 11,368 & 11.920 & 11,920 \\
\hline $\mathrm{R}^{2}$ & 0.0223 & 0.0223 & 0.0225 & 0.0225 \\
\hline Dependent variable & \multicolumn{4}{|c|}{ O-score (Cutoff point of .038) } \\
\hline
\end{tabular}


The dependent variable in these models is the abnormal return starting three days after the earnings announcement and ending the day before the next earnings announcement. DIST is the variable for distress, which we calculate Ohlson's O-score. DIST $=1$ if the $\mathrm{O}$-score is greater than or equal to 0.038 . DIST $=0$ if the $\mathrm{O}$-score is less than 0.038 . SUE_WALK and SUE are the earnings surprise based on a random walk and analyst forecasts, respectively. DIST*SUE_WALK and DIST*WALK are interaction variables. CHFORCAST is the change in the analyst forecast between the first and last analyst in the 90 days before the earnings announcement. CHFORCAST*DIST is an interaction variable between the distress indicator variable. NUMEST is a count of the number of analyst estimates of the quarterly earnings for the quarter in question. Distress Variable measures distress. ***, **, * represent significance at the $1 \%, 5 \%$, and $10 \%$ level, respectively.

\section{Conclusion}

Managers of distressed firms are more concerned about losing their jobs than managers of non-distressed firms. They are more willing to engage in earnings management that allows them to meet expectations. However, there are consequences to engaging in this behavior. We contribute to the earnings management, earnings surprise, and distress literatures by documenting a significant relation between firm distress and earnings management. In addition, we show that investors detect and respond to earnings management by distressed firms.

We contribute to the earnings management literature by providing evidence of an increase in earnings management at distressed firms after failure to meet analyst expectations. We find evidence that the value of discretionary accruals is significantly greater for distressed firms than non-distressed firms. Our results indicate that managers of distressed firms increase discretionary accruals after a negative earnings surprise while managers of distressed firms do not. Our analysis supports the hypothesis that managers of distressed firms engage in greater earnings management.

Next we examine the impact that lower earnings quality has on the investor response to earnings surprises. We find that investors are significantly less responsive to earnings surprises of distressed firms. Our results are robust to different matching schemes, earnings surprise measures, return windows, and distress variables.

Distressed firms experience larger-in-magnitude investor response to positive earnings surprises than negative earnings surprises. This finding is consistent with the bankruptcy avoidance effect. The investor response to negative earnings surprises of non-distressed firms is significantly larger than the response for positive earnings surprises, consistent with prior research.

Finally, we examine the post-earnings announcement drift of distressed firms. We show that these firms exhibit smaller post-earnings announcement drift than non-distressed firms. Taken together, our evidence indicates that poor earnings quality makes investors less responsive to earnings surprises of distressed firms than to earnings surprises of non-distressed firms.

The ability to manage discretionary accruals is used by managers of distressed firms, who are likely under greater pressure than managers of non-distressed firms. Our findings are important because they indicate that there are consequences to managing earnings that may not have been foreseen by managers. Compensation committees should be aware of the tendency of the managers of distressed firms to manage earnings if compensation is dependent on reported earnings. Similarly, the audit committee of a distressed firm should be concerned about earnings quality and the signal that it sends to investors.

\section{Acknowledgements}

We would like to thank Michael O'Doherty, David Maslar, Michael Gibbs, Shastri Sandy, Eliza Zhang, Josh Gunn, Musa Subasi, and Raynolde Periera for their helpful comments.

\section{References}

Altman, E. (1968). Financial Ratios, Discriminant Analysis and the Prediction of Corporate Bankruptcy. Journal of Finance, 23(4), 589-609. http://dx.doi.org/10.1111/j.1540-6261.1968.tb00843.x

Bartov, E., D. Givoly, \& C. Hayn. (2002). The Rewards to Meeting or Beating Earnings Expectations. Journal of Accounting and Economics, 33(2), 173-204. http://dx.doi.org/10.1016/S0165-4101(02)00045-9

Becchetti, L., \& J. Sierra. (2003). Bankruptcy Risk and Productive Efficiency in Manufacturing Firms. Journal of Banking and Finance, 27(11), 2099-2120. http://dx.doi.org/10.1177/0266242613517126 
Becker, C., M. DeFond, J. Jiambalvo, \& K.R. Subramanyam. (1998). The Effect of Audit Quality on Earnings $\begin{array}{lllll}\text { Management. Contemporary Accounting } & \text { Research, } & 16, & 1-24 .\end{array}$ http://dx.doi.org/10.1111/j.1911-3846.1998.tb00547.x

Beneish, M., E. Press, \& M. Vargus. (2012). Insider Trading and Earnings Management in Distressed Firms. Contemporary Accounting Research, 29(1), 191-220. http://dx.doi.org/10.1111/j.1911-3846.2011.01084.x

Bergstresser, D., \& T. Philippon. (2006). CEO incentives and earnings management. Journal of Financial Economics, 80(6), 511-529. http://dx.doi.org/10.1016/j.jfineco.2004.10.011

Bernard, V. L., \& J. K. Thomas. (1989). Post-Earnings-Announcement Drift: Delayed Price Response or Risk Premium? Journal of Accounting Research, 1-36. http://dx.doi.org/10.2307/2491062

Burgstahler, D., \& I. Dichev. (1997). Earnings Management to Avoid Earnings Decreases and Losses. Journal of Accounting and Economics, 24(1), 99-126. http://dx.doi.org/10.1016/S0165-4101(97)00017-7

Campbell, J. Y., J. Hilscher, \& J. Szilagyi. (2008). In Search of Distress Risk. Journal of Finance, 63(6), 2899-2939. http://dx.doi.org/10.3386/w12362

Campbell, L., Liu, L., \& Kasey Martin. (2015). Accrual Earnings Management Prior to Delisting. Journal of Accounting and Finance, 15(3), 53. http://dx.doi.org/10.2308/jltr-51192

Charitou, A., N. Lambertides, \& L. Trigeorgis. (2007). Earnings Behavior of Financially Distressed Firms: The Role of Institutional Ownership. ABACUS, 43(3), 271-296. http://dx.doi.org/10.1111/j.1467-6281.2007.00230.x

Chemmanur, T., Y. Cheng, \& T. Zhang. (2013). Human Capital, Capital Structure, and Employee Pay: An Empirical Analysis. Journal of Financial Economics, 110(2), 478-502. http://dx.doi.org/10.2139/ssrn.1099000

Chudek, M., C. Truong, \& M. Veeraraghavan. (2011). Is trading on Earnings Surprises a Profitable Strategy? Canadian Evidence. Journal of International Financial Markets, Institutions and Money, 21(5), 832-850. http://dx.doi.org/10.2139/ssrn.1783049

Dahya, J., J. J. McConnell, \& N. G. Travlos. (2002). The Cadbury Committee, Corporate Performance, and Top Management Turnover. Journal of Finance, 461-483. http://dx.doi.org/10.1111/1540-6261.00428

DeAngelo, H., L. DeAngelo, \& D. Skinner. (1994). Accounting Choice in Troubled Companies. Journal of Accounting and Economics, 17(1), 113-143. http://dx.doi.org/10.1016/0165-4101(94)90007-8

Dechow, P. M., R. G. Sloan, \& A. P. Sweeney. (1995). Detecting Earnings Management. Accounting Review, 70(2), 193-225.

DeFond, M. L., \& J. Jiambalvo. (1994). Debt covenant violation and manipulation of accruals. Journal of Accounting and Economics, 17(1), 146-176. http://dx.doi.org/10.1016/0165-4101(94)90008-6

Degeorge, F., J. Patel, \& R. Zeckhauser. (1999). Earnings Management to Exceed Thresholds. Journal of Business, 72(1), 1-33. http://dx.doi.org/10.1086/209601

Dellavigna, S., \& J. M. Pollet. (2009). Investor Inattention and Friday Earnings Announcements. Journal of Finance, 64(2), 709-749. http://dx.doi.org/10.1111/j.1540-6261.2009.01447.x

Doyle, J. T., J. N. Jennings, \& M. T. Soliman. (2013). Do Managers Define non-GAAP Earnings to Meet or Beat Analyst Forecasts? Journal of Accounting and Economics, 56(1), 40-56. http://dx.doi.org/10.2139/ssrn.1933882

Ebrahim, A. (2007). Earnings management and board activity: an additional evidence. Review of Accounting and Finance, 6(1), 42-58. http://dx.doi.org/10.1108/14757700710725458

Etemadi, H., Dastgir, M., Momeni, M., \& Hassan Dehkordi. (2012). Discretionary Accruals Behavior of Iranian Distressed Firms. Middle Eastern Finance and Economics, 16, 44-53. http://dx.doi.org/10.5897/AJBM11.2543

Franz, D. R., HassabElnaby, H. R., \& Gerald J. Lobo. (2014). Impact of proximity to debt covenant violation on earnings management. Review of Accounting Studies, 19(1), 473-505. http://dx.doi.org/10.2139/ssrn.2195351

García, L., Manuel, J., Osma, B., \& Evi Neophytou. (2009). Earnings quality in ex - post failed firms. Accounting and Business Research, 39(2), 119-138. http://dx.doi.org/10.1080/00014788.2009.9663353

Griffin, H., \& M. L. Lemmon. (2002). Book-to-Market Equity, Distress Risk, and Stock Returns. Journal of Finance, 2317-2336. http://dx.doi.org/10.1111/1540-6261.00497

Huson, M. R., P. H. Malatesta, \& Robert Parrino. (2004). Managerial Succession and Firm Performance. Journal of Financial Economics, 74(2), 237-275. http://dx.doi.org/10.1.1.194.5549 
Jensen, M. (1991). Corporate Control and the Politics of Finance. Journal of Applied Corporate Finance, 4(2), 13-33. http://dx.doi.org/10.1111/j.1745-6622.1991.tb00603.x

Jones, J. (1991). Earnings Management during Import Relief Investigations. Journal of Accounting Research, 193-228. http://dx.doi.org/10.2307/2491047

Kalay, A., R. Singhal, \& E. Tashjian. (2007). Is Chapter 11 costly? Journal of Financial Economics, 84(3), 772-796. http://dx.doi.org/10.1016/j.jfineco.2006.04.001

Ke, B., and S. Ramalingegowda. (2005). Do Institutional Investors Exploit the Post-Earnings Announcement Drift? Journal of Accounting and Economics, 39(1), 25-53. http://dx.doi.org/10.1016/j.jacceco.2004.02.002

Klein, A. (2002). Audit Committee, Board of Director Characteristics, and Earnings Management. Journal of Accounting and Economics, 33(3), 375-400. http://dx.doi.org/10.2308/accr.2002.77.2.435

Kothari, S.P., S. Shu, \& P. Wysocki. (2009). Do Managers Withhold Bad News? Journal of Accounting Research, 47(1), 241-276. http://dx.doi.org/10.1111/j.1475-679X.2008.00318.x

Livnat, J., \& R. Mendenhall. (2006). Comparing the Post-Earnings Announcement Drift for Surprises Calculated from Analyst and Time Series Forecasts. Journal of Accounting Research, 44(1), 177-205. http://dx.doi.org/10.1111/j.1475-679X.2006.00196.x

Michaely, R., R. Thaler, \& K. Womack. (1995). Price Reactions to Dividend Initiations and Omissions: Overreaction or Drift? Journal of Finance, 573-608. http://dx.doi.org/10.1111/j.1540-6261.1995.tb04796.x

Ohlson, J. A. (1980). Financial Ratios and the Probabilistic Prediction of Bankruptcy. Journal of Accounting Research, 109-131. http://dx.doi.org/10.2307/2490395

Peasnell, K. V., Pope, P., \& Steven Young. (2005). Board monitoring and earnings management: do outside directors influence abnormal accruals?. Journal of Business Finance \& Accounting, 32(7 - 8), 1311-1346. http://dx.doi.org/10.1111/j.0306-686X.2005.00630.x

Price, S. M., D. Gatzlaff, \& C. F. Sirmans. (2012). Information Uncertainty and the Post-earnings-Announcement Drift Anomaly: Insights from REITs. Journal of Real Estate Finance and Economics, 44(1-2), 250-274. http://dx.doi.org/10.1007/s11146-010-9275-y

Puffer, S., \& J. Weintrop. (1991). Corporate Performance and CEO Turnover: The Role of Performance Expectations. Administrative Science Quarterly, 1-19. http://dx.doi.org/10.2307/2393427

Rangan, S. (1998). Earnings Management and the performance of Seasoned Equity Offerings. Journal of Financial Economics, 50(1), 101-122. http://dx.doi.org/10.1016/S0304-405X(98)00033-6

Rangan, S., \& R. G. Sloan. (1998). Implications of the Integral Approach to Quarterly Reporting for the $\begin{array}{llll}\text { Post-Earnings-Announcement } & \text { Drift. } & \text { Accounting } & \text { Review, }\end{array}$ http://dx.doi.org/10.1111/j.1475-679X.2011.00425.x

Rosner, R. (2003). Earnings Manipulation in Failing Firms. Contemporary Accounting Research, 20(2), 361-408. http://dx.doi.org/10.1506/8EVN-9KRB-3AE4-EE81

Roychowdhury, S. (2006). Earnings management through real activities manipulation. Journal of Accounting and Economics, 42(3), 335-370. http://dx.doi.org/10.1016/j.jacceco.2006.01.002

Sadka, R. (2006). Momentum and Post-Earnings Announcement Drift Anomalies: The Role of Liquidity Risk. Journal of Financial Economics, 80(2), 309-349. http://dx.doi.org/10.1016/j.jfineco.2005.04.005

Saleh, N., \& K. Ahmed. (2005). Earnings Management of Distressed Firms during Debt Renegotiation. Accounting and Business Research, 35(1), 69-86. http://dx.doi.org/10.1080/00014788.2005.9729663

Shumway, T. (2001). Forecasting Bankruptcy More Accurately: A Simple Hazard Model. Journal of Business, 74(1), 101-124. http://dx.doi.org/10.1086/209665

Siregar, S. V., \& Sidharta Utama. (2008). Type of earnings management and the effect of ownership structure, firm size, and corporate-governance practices: Evidence from Indonesia. The International Journal of Accounting, 43(1), 1-27. http://dx.doi.org/10.1016/j.intacc.2008.01.001

Skinner, D., \& R. Sloan. (2002). Earnings Surprises, Growth Expectations, and Stock Returns or Don't Let an Earnings Torpedo Sink Your Portfolio. Review of Accounting Studies, 7(2-3), 289-312. http://dx.doi.org/10.1023/A:1020294523516 
Smith, C. (1993). A Perspective on Accounting-Based Debt Covenant Violations. Accounting Review, 289-303. http://dx.doi.org/10.1177/0148558X0201700402

Teoh, S. H., I. Welch, \& T.J. Wong. (1998). Earnings Management and the Long-Run Market Performance of Initial Public Offerings. Journal of Finance, 53(6), 1935-1974. http://dx.doi.org/10.1111/0022-1082.00079

Yu, F. F. (2008). Analyst coverage and earnings management. Journal of Financial Economics, 88(2), 245-271. http://dx.doi.org/10.1016/j.jfineco.2007.05.008

Zhang, Y. (2008). Analyst Responsiveness and the Post-Earnings Announcement Drift. Journal of Accounting and Economics, 46(1), 201-215. http://dx.doi.org/10.2139/ssrn.647687

\section{Notes}

Note 1. For example, see Defond and Jiambalvo (1994).

Note 2. The final model we use is Altman's Z-score (1968). Griffin and Lemmon (2002) find that this model predicts delisting less accurately than the O-score model. However, several studies have shown Altman's Z-score to be accurate (Bartov, Givoly, \& Hayn 2002; Shumway 2001). We recalculate Z-scores for firms annually and classify firms as distressed if they have Altman Z-scores below 1.81. Non-distressed firms have Z-scores above 2.99. We drop firm observations with Z-scores between 1.81 and 2.99 because of the ambiguity of whether they are distressed. This method is consistent with previous studies (Bartov, Givoly, \& Hayn 2002).

Note 3. We also test earnings surprise with the standard deviation of returns in the denominator and find similar results throughout our paper.

Note 4. Although not included, our results do not change when we include earnings guidance. We find a significant and positive relation between earnings guidance and abnormal returns. It appears that investor response to earnings surprises is significantly larger when the firm provides guidance. Distressed firms are significantly less likely to provide earnings guidance in the months prior to a quarterly earnings announcement (not tabulated).

Note 5. Although not reported in Table 3, we test the robustness of our results using the Z-score. We classify firms as distressed if the Altman Z-score is below 1.81 and drop observations where the Z-score is between 1.81 and 2.99. We classify all other observations as non-distressed. The results are qualitatively similar to those we report.

Note 6. Although not shown, we examine the drift for both positive and negative surprises and find that stock prices in our sample drift in the direction of our earnings surprises. 